\title{
Ardahan Yöresi Düz Dokumaları
}

Mevlüt KAPLANOĞLU*

Flat Weavings of Ardahan Region

\section{ÖZET}

Ardahan yöresinde düz dokumaların zenginliği ipek yolunun önemli merkezlerinden Ahıska'ya sınır olması ve Anadolu'dan Orta Asya'ya açılan kapılardan bir tanesi olmasıdır. Zira bu ipek yolundaki Ardahan bölgesinde yerleşik hayat kuran ve kökleri Orta Asya'ya dayanan Türk kavimlerin dokuma kültürünü zenginleştirerek devam ettikleri görülmektedir. Ardahan yöresi düz dokumaları denilince akla Ardahan merkez olmak üzere, Çıldır, Posof, Hanak, Damal ve Göle yöresinde dokunan kilim, cicim, zili vb. dokumalar akla gelir. Geometrik ve bitkisel desenlerin ağırlıklı olarak kullanıldığı yöre dokumalarında dokuma tekniklerine göre Ahıskalı, karapapak, yerli kilimi gibi yöresel adlarda kullanılmaktadir.

Söz konusu dokumalar, kullanım amaçlarına ve kullanıldıkları yerlere göre seccade, divan yastığı, yer sergisi, yük örtüsü gibi adlar alırlar. Ardahan yöresindeki düz dokumalar kendine has yöresel özelliklerin yanı sıra; Anadolu'daki diğer yaygılarla da ortak özellikler göstermektedir. Düz dokuma yaygılarının malzemesi yündür. Siyah, kahverengi ve beyaz renkli yünler boyamadan saf olarak kullanılır. Boyalar eskiden doğal malzeme ve bitkilerden elde edilmiş olup, günümüzde sentetik ve doğal boyalar birlikte kullanılmaktadır. Kırmızı, siyah, kahverengi, yeşil ve beyaz renkler hâkimdir. Tek ve iki şak halinde dokunur.
Seccade tipi örneklerde, kenar suları üsluplaşmış lale, karanfil ve hayat ağacı motifleri, zeminde ise kandil ve ibrik benzeri motifler görülür.

Anahtar Kelimeler: Ardahan, Düz Dokuma, Kilim, Atkı, Çözgü.

\section{ABSTRACT}

Ardahan region is famous for its flat weaving. The region is close to Ahıska, which is an important settlement of the Silk Road connecting Anatolia to Central Asia. In terms of their rich weaving culture the settlers in the Ardahan region are the descendants of the Turkish people in the Central Asia. When Ardahan region flat weaving is mentioned; Ardahan as the center, Çıldır, Posof, Hanak, Damal and Göle regions woven kilims, cicim, zili and etc. come to the fore. In this region geometric and plant figures are widely used, traditional names such as Ahıskalı, karapapak and domestic kilim are also used.

The mentioned weaving names are determined according to their functions and locations such as: rugs, divan pillows, ground exhibition, load covers. In addition to the domestic charecteristics of Ardahan region plain weavings, it also shows common features with other Anatolian examples. The plain wovens' materials are wool. Black, Brown and White color wools are purely used. The colors are made up of natural material and plants in the past, but today, synthetic and natural paints are used together. Red, black, brown, green and white 
colors are dominant. One and two smacks are used. In the examples of prayer rug type, tulips treated with bank waters, clove and life tree motifs, and in the ground, motifs like Keresone lamp and ewer are used.

Keywords: Ardahan, Plain Woven, Rug, Weft, Warp.

Anadolu'nun kuzeydoğusunda yer alan Ardahan, yakın tarihlere kadar Kars'a bağlı bir ilçe merkezi iken, 1992 yılında Bakanlar Kurulu Kararı ile ayrı bir il haline getirilmiş. ' Ardahan'a adını veren kavmin M.Ö. VI. Asırda bu yörede yerleşen ve Kıpçaklar'ın kolu olan Arda Boyu olduğu sanılmaktadır². Ancak Orta Asya kökenli Hunlar'ın batıya doğru Milattan Önceki VI.-VII. yüzyıllara dayanan ilk hareketleri sırasında buralara gelip yerleşen ve Ural-Altay dil ailesine bağlanan kavimler, buralarda ilk derli toplu yerleşimi sağlayan gruplar olmuştur ${ }^{3}$. Ardahan'ın iskân yeri olarak seçiminde ve kuruluşunda kentin içinden geçen Kura (kür) Nehri'nin önemli bir fonksiyonu olduğu anlaşılmaktadır. ${ }^{4}$

Büyük Selçuklular bu yöreye ilkin, Tuğrul Bey zamanında ve İbrahim Yınal komutasında organize birlikler oluşturarak yerleşmeye başlarlar. Önce Azerbaycan, sonra da Gürcistan'ı ve Çıldır'ı ele geçiren Selçuklular, 1067 yılında yani Malazgirt Zaferi'nden bir süre önce bu yörede hâkim güç olarak varlıklarını hissettirirler ${ }^{5}$. Çıldır'la birlikte Ardahan halkı içerisinde çoğunluğu oluşturan Oğuzlar'ın Karapapak Boyu'ndan gelen Terekemeler'in, zaman zaman başka adlarla da olsa bu yöreleri hâkimiyeti altında bulunduran devletlerin şemsiyesi altında kalmalarına rağmen, yörenin bu etnik yapısı, hemen hemen hiç değişmeden günümüze kadar gelmiştir. ${ }^{6}$

Bugün Ardahan merkez ilçesine bağlı beş ilçe bulunmaktadır. Bunlar Göle, Çıldır, Damal, Hanak ve Posof'tur. (Tablo: 1)

Ardahan il haline getirildikten sonra kuzey ve kuzeydoğudan Acaristan, Gürcistan ve kısmen de olsa Ermenistan, güneydoğu ve güneyden Kars ve Erzurum, batıdan da Artvin illeriyle sınır komşusu olmuştur.

\footnotetext{
H. Gündoğdu, Kaleler ve Kuleler Kenti Ardahan, Ankara, 2000, s. 6.

F. Kırzıŏlu, Kars Tarihi, C. I, İstanbul, 1953, s. 17-29.

M. Önder, Şehirden şehre Anadolu, Ankara, 1995, s. 54.

Gündoğdu, age., ss.6-7.

E. Konukçu, Ardahan Tarihi, Ankara, 1999, s. 47

Konukçu, age., s. 47.
}

Tablo 1: Araştırma Kapsamına Giren İl, İlçe ve Köyler

\begin{tabular}{|l|l|l|l|l|l|}
\hline $\begin{array}{l}\text { Ardahan } \\
\text { Merkez }\end{array}$ & Hanak & Çıldır & Damal & Posof & Göle \\
\hline Merkez & Merkez & Merkez & Merkez & Merkez & Merkez \\
\hline Hasköy & $\begin{array}{l}\text { Avcılar } \\
\text { köyü }\end{array}$ & Akçakale & $\begin{array}{l}\text { Cumhuriyet } \\
\text { Mahallesi }\end{array}$ & Alköy & \\
\hline Kazlı köy & $\begin{array}{l}\text { Koyun } \\
\text { pınar }\end{array}$ & & & $\begin{array}{l}\text { Asmalı } \\
\text { konak }\end{array}$ & \\
\hline $\begin{array}{l}\text { Sulakyurt } \\
\text { (sarzep) }\end{array}$ & & & & Aşızülali & \\
\hline & & & & Baykent & \\
\hline & & & & Kırdamalı & \\
\hline & & & & Yeniköy & \\
\hline
\end{tabular}

Türk dokuma sanatları grubuna giren, halı dişında kalan, Türk düz dokuma yaygıları, teknik açıdan, kilim, cicim, zili, sumak (verneh) olmak üzere dört ayrı tip dokuma tekniği adı altında incelenir. Bu düz dokuma yaygllar enine ve dikey, iki veya daha fazla iplik sistemine dayanılarak yapılan, birbiri arasından değişik şekillerde geçerek, düğümsüz ve havsız (tüysüz) dokunan, yer yaygısı, yastık, örtü, perde vb. amaçla kullanılan yaygı türlerine "düz dokuma yaygılar" denir.

Bu sanatın Asya'dan başlayıp Avrupa'ya kadar uzandığı bilim dünyasınca tartışmasız kabul edilen bir gerçektir. Bu gerçeği ortaya koyan dokuma örneklerinden önemli bir grupta milattan önceki asırlardan itibaren Asya'dan gelerek Ahıska ve Ardahan yöresine yerleşen Türk kavimlerinin ürettikleri dokumalardır.

Ardahan yöresinde düz dokumaların zenginliği ipek yolunun önemli merkezlerinden Ahıska'ya sınır olması ve Anadolu'dan Orta Asya'ya açılan kapılardan bir tanesi olmasıdır. Zira bu ipek yolundaki Ardahan bölgesinde yerleşik hayat kuran ve kökleri Orta Asya'ya dayanan Türk kavimlerin dokuma kültürünü zenginleştirerek devam ettikleri görülmektedir. Ardahan yöresi düz dokumaları denilince akla Ardahan merkez olmak üzere, Çıldır, Posof, Hanak, Damal ve Göle yöresinde dokunan kilim, cicim, zili vb. dokumalar akla gelir. Geometrik ve bitkisel desenlerin ağırlıklı olarak kullanıldığı yöre dokumalarında görülen motifler ise, geometrik, bitkisel hayvan motifleri, mimari tasvirler (cami gibi) ve sembolik motiflerdir. Dokuma tekniklerine göre Ahıskalı, karapapak, yerli kilimi gibi yöresel adlarda kullanılmaktadır. Söz konusu dokumalar, kullanım amaçlarına göre seccade, divan yastığı, yer sergisi, yük örtüsü gibi adlar alırlar. Ardahan yöresindeki düz dokumalar kendine has yöresel özelliklerin yanı sıra; Anadolu'daki diğer yaygılarla da ortak özellikler göstermektedir.

Tek ve iki şak halinde dokunur. Seccade tipi örneklerde, üsluplaşmış lale, karanfil ve hayat ağacı motifleri, zeminde ise kandil ve ibrik benzeri motifler görülür.

Teknik, malzeme ve desen açısından bölgesel özelliklerin yanında geleneksel özellikleri de bünyesinde barındıran Ahıska ve Ardahan yöresi dokumalarını günümüze kadar ayrıntılı bir şekilde tanıtan 
yayın neredeyse yapılmamıştır. Bu nedenle yöredeki dokumaların ayrıntılı bir biçimde bilim dünyasına tanıtmak; Türk ve Dünya kültürüne kazandırmak inancından hareketle, bu çalışmayı lüzumlu gördük. Yaptığımız çalışma sonucunda 100'e yakın düz dokuma tespit edilmiştir. Tespit edilen bu dokumaların orijinalliğine sadık kalınarak bilgisayar ortamında yeniden çizilerek arşivlenmiştir. Burada birkaç önemli örneğini gösterme fırsatını bulabilmekteyiz.

\section{Ardahan Yöresi Düz Dokumalarında Kullanılan hammadde}

Düz dokuma yaygılarının hammaddesini yün ve pamuk ipliği oluşturmaktadır. Ardahan ve yöresinde, kırlarda otlayan koyunun yılda bir kez haziran sonu ya da temmuzun başında, besiye alınan koyunlar ise yılda iki üç defa kırkımı yapılır. Bazı yörelerde kuzular 78 aylıkken, Ağustos ve Eylül ayları içinde sürülerden ayrı olarak yalnız sırt ve kaburga tarafındaki yünler kırkılır, erkek kuzuların kuyruk bölümü kırkılmaz. Bunun nedeni, yörede erkek kuzunun kuyruk kısmından daha çabuk üşüdüğü fikrinin yaygın olmasıdır. Dişi kuzu üşümeye karşı daha dayanıklıdır. Ardahan ve yöresinde kışların uzun ve havaların soğuk olmasından dolayı kışı ahırlarda geçiren koyunların yünlerinde idrar ve pisliklerden meydana gelmiş, siyeklerle çakıldaklar fazladır. Kırkım ayında, bu iş için özel olarak yapılmış makaslar kullanılır. Kirli olan yapağılar, Dere kenarlarında ya da çeşme başlarında tokaçlanarak yıkanır. Çok kirli olan kısımlar suda birkaç gün bekletilerek kirlerinin yumuşaması sağlanır. Yıkama esnasında pislik ve kirlerin yanı sıra yünde doğal olarak bulunan yağ da bir nebze temizlenir. Yıkanan yünlerin oldukça yumuşak olması isteniyorsa yün ıslatıldıktan sonra üzerine meşe külü serpilir daha sonra durulanır. Ağaç seleler içine doldurulan yapağılar taşlar üzerinde süzülerek kurutulur. Kurutulan yünler, eriş ve argaç olacak şekilde ayrıma tabi tutulur. ${ }^{7}$

Ardahan Yöresi'nde yünün tarama işlemi ise, diğer yörelerde olduğu gibi, eğrilecek ipliğe göre ayırt edilen yünler, el yardımıyla ayrıştırarak özel hazırlanmış taraklarla taranır. Geçmişte el tarağında, şimdi ise makine tarağında ya da taranmadan el yardımıyla yünler eğrilmeye uygun hale getirilir. Kullanılan tarakların farklı şekillerde olanları vardır. Ardahan Yöresi'nde kullanılan kalın bir tahtanın ortasına veya uç tarafına kısa kenarlarına paralel olarak çakılmış, iki sıra sivri uçlu çelik çubuklardan yapılmaktadır. Dokunmak için ayrılıp yıkanan yünler, ilk önce yün tarağında iş bilir tecrübeli kadınlar tarafından iyice taranır. İplik haline getirilmek üzere, kaplara doldurulur ve yine tecrübeli kadınlar tarafından eğrilerek iplik haline getirilir. ${ }^{8}$

\footnotetext{
T. Parlak, Oltu ve Köylerinde Bardı Kilimciliăi, Erzurum, 2002, s. 1921.

8 T. Parlak, age., ss. 19-21,
}

Günümüzde çözgüde kullanılan pamuk ise, dışarıdan getirilmektedir. Ancak, Ardahan yöresinde koyunlardan elde edilen yün ipliği tercih edilmektedir. Kullanılan yün iplikleri gerek evlerde el eğirmesi, gerekse fabrikalardan temin edilmektedir. Son yıllarda Ardahan'da kilim dokumasında kullanılan ipliğin büyük bir kısmı iplik fabrikalarından temin edilmektedir.

\section{Ardahan Yöresi Düz Dokumalarında Kullanılan Araç Gereçler}

Ardahan ve yöresinde yapılan araştırma kapsamında, il merkezi dışında dokuma yapan ilçe ve köy bulunamadığından dokuma yapan tezgâha da rastlanmamıştır. Ancak il merkezinde ardan valiliği sosyal yardımlaşma vakfı denetiminde büyük bir atölye işler durumdadır. Burada kullanılan tezgâh tipi ise metal sarma tipi tezgâhlardır. Araştırmalar sonucunda, bu bölgede dokumaların yapıldığı yıllarda düz dokuma yaygılarda halkın ağaç tezgâh, gergi ağacı, ip ağacl gibi isimlerle adlandırdığı, ahşaptan yapılmış yarı yatık ıstar tipi tezgâhlar kullanıldığı tespit edilmiştir.

Ardahan ve yöresinde günümüzde demir kirkitler kullanılmaktadır. İplikleri kesmek için "küçük bıçaklar", yumak yapmaya da "gülcan" denilen aletler kullanılır. "Verep" denilen küçük ağaç mekikler üzerine ipler sarılarak dokuma yapılır. Ayrıca Ardahan ve Yöresi'nde çok eskilere dayanan yün iplik yapımı, teşi, iğ ve çıkrık denilen aletlerle yapılmaktadır.

\section{Ardahan Yöresi Düz Dokumalarında Kullanılan Boyalar}

İncelenen örneklerin çoğunda kimyasal boyalarla doğal boyalar birlikte kullanılmıştır. Ancak yapılan mülakatlar ve bazı doğal, kimyasal karışık örneklerin incelenmesi neticesinden anlaşıldığı üzere yörede doğal boya ile oldukça kaliteli örneklerin geçmişte yapıldığını belgelemiştir. Siyah, kahverengi ve beyaz renkli yünler boyamadan saf olarak kullanılmaktadır. Boyalar eskiden doğal malzeme ve bitkilerden elde edilmiş olup, yakın bir zamana kadar da sentetik ve doğal boyalar birlikte kullanılmaktadır. Kırmızl, siyah, kahverengi, yeşil ve beyaz renkler hâkimdir. Ancak günümüzde dokuma teknikleriyle birlikte doğal boya geleneği de unutulmuştur. 15-20 yıl önceleri eğrilen yün iplikler ise Ardahan ya da Kars'daki kimyasal boya yapan boyacı ustalara yaptırılmaktaydı. Günümüzde, dokumacılıkta kullanılan ipliklerin tamamı Isparta, Kayseri ve diğer halı bölgelerinden hazır boyanmış olarak alınmaktadır.9

Araştırma bölgesindeki yöre halkı, düz dokumalarda kullandıkları boya bitkilerin toplama zamanlarını iyi bilmektedirler. Araştırma bölgesi Ardahan ve yöresinde bol miktarda kendiliğinden yetişen özelliklede Posof bölgesinde Türk kırmızısı ve Çivit otu

T. Parlak, "Çoruh Vadisinde Bitkisel Boya Potansiyeli", Ankara, 2007, s. 47. A. Aytaç, Hotamış Türkmen Kilimleri, Konya, 2003, s.16-17. 
bitkisi bulunmaktadır. Sütleğen, mazı, sarı muhabbet çiçeği, sarıpapatya, altın otu, hava cıva, kantaron, ceviz kabuğu, çivit otu, kök boya, soğan kabuğu gibi bitkisel boyalar kullanılmıştır. Boyacı kökü olarak ta bilinen Türk kırmızısı bitkisinden kırmızı ve tonları elde edilmektedir.

Beyaz, Ardahan ve yöresinde, genellikle saf olarak kullanılır. İplikler killi toprak içerisinde ağartılır.

\section{Ardahan Yöresi Düz Dokumalarında Kullanılan Motifler}

Araştırma sahamızdaki düz dokumalarında kullanılan motifleri şu şekilde sıralayabiliriz; Sembolik, geometrik, hayvansal, bitkisel, damga / imler ve yazı tipi motifi olarak sıralaya biliriz.
Ardahan ve yöresinde en çok kullanılan motifler; Elibelinde motifi, Koçboynuzu motifi, Bereket motifi, Saç Bağı, Küpe, Bukağı motifi, Sandıklı motif, Aşk ve Birleşim motifi, Yıldız, Pıtrak, El, Parmak ve Tarak motifleri, Muska ve Nazarlık motifleri, Göz motifi, Oğ Damgası (Haç motifi), Türkmen Gülü, Madalyon, Çengel (Çakmak) motifi, Deve Boynu, Deve Tabanı, Ejder motifi, Akrep motifi, Kurt Ağzı, Kurt İzi, Canavar Ayağı, Hayat Ağacı, Yol/Kıvrımlı Yol, ÇiçekYaprak motifi, Karanfil, Kandil motifi, İbrik motifi, Kuş motiflerini sayabiliriz.

Tespit edilen Ardahan yöresi düz dokumalarından birkaç örneği aşağıda fotoğraflarıyla birlikte yeni çizimleri birlikte verilmiştir.

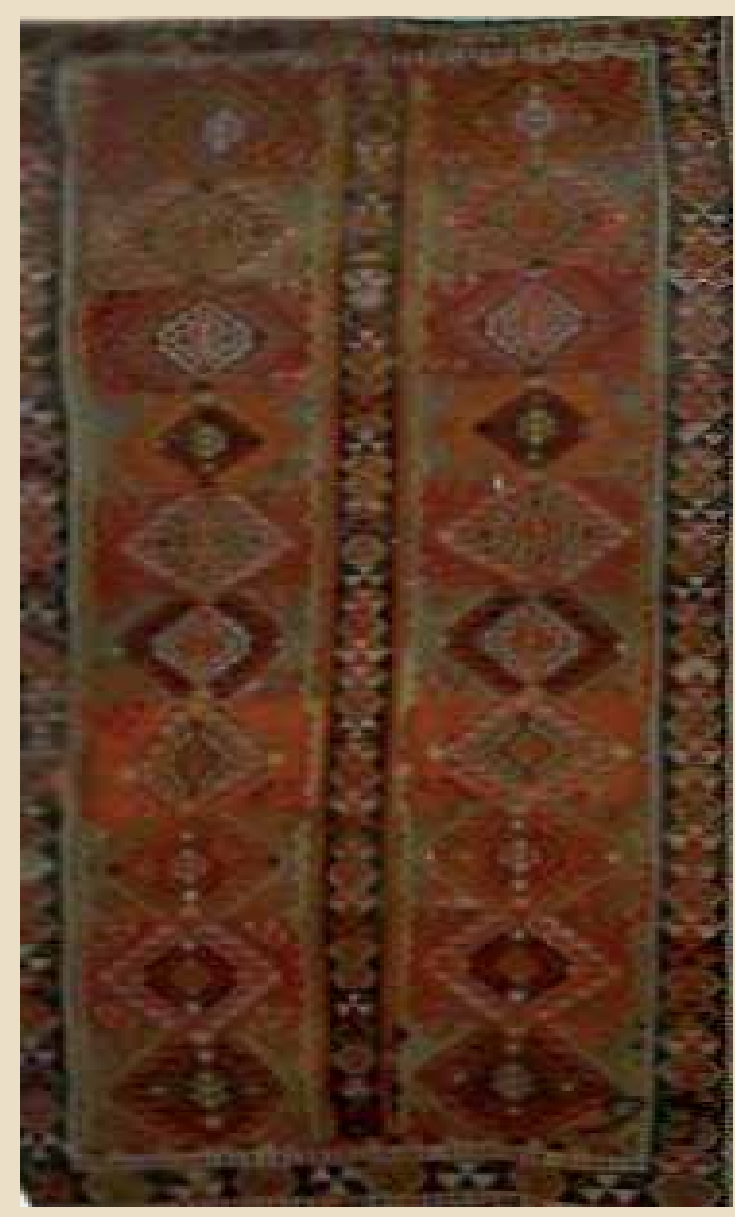

Foto 1.

Dikdörtgen formunda olan bu kilim, Posof / Aşıkzülali köy camisinde bulunmaktadır. 130x315 $\mathrm{cm}$ ebatlarında ilikli kilim tekniğinde, zemini ince bir bordürle iki parçaya ayrılmış olup birbirine bağlı baklava dilimleri ile sıralanmıştır. Baklava dilimlerinin içerisine çengel (bereket) motifi yerleştirilmiştir. Zemini iki parçaya ayıran şerit

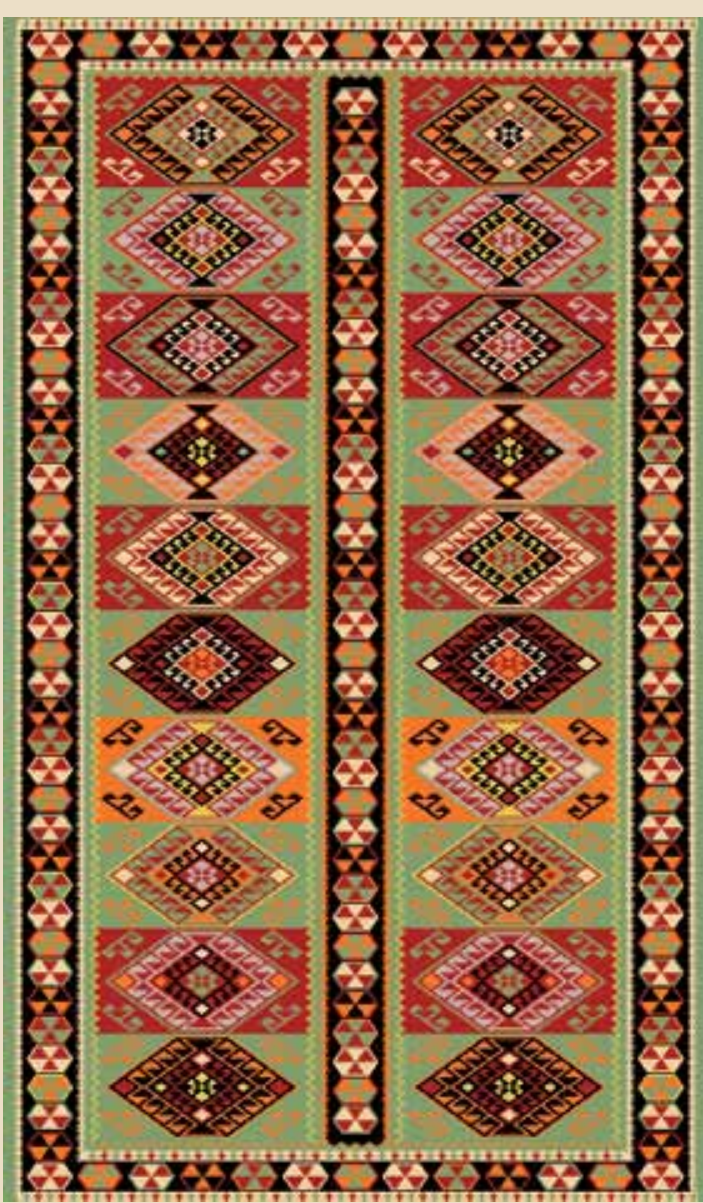

Çizim 1.

ve bordürler taraklarla zeminden ayrılmıştır. Şerit ve bordürde altıgenler ve bu altıgenlerin içerisine muska motifi yerleştirilmiştir. Kullanılan renklere baktığımız zaman kırmızı, sarı, yeşil, siyah ve beyaz renkleri görebilmekteyiz. Desen ipliği ve çözgü yün malzemeden kullanılmış olup tamamen doğal boya renkleriyle boyanmıştır. 


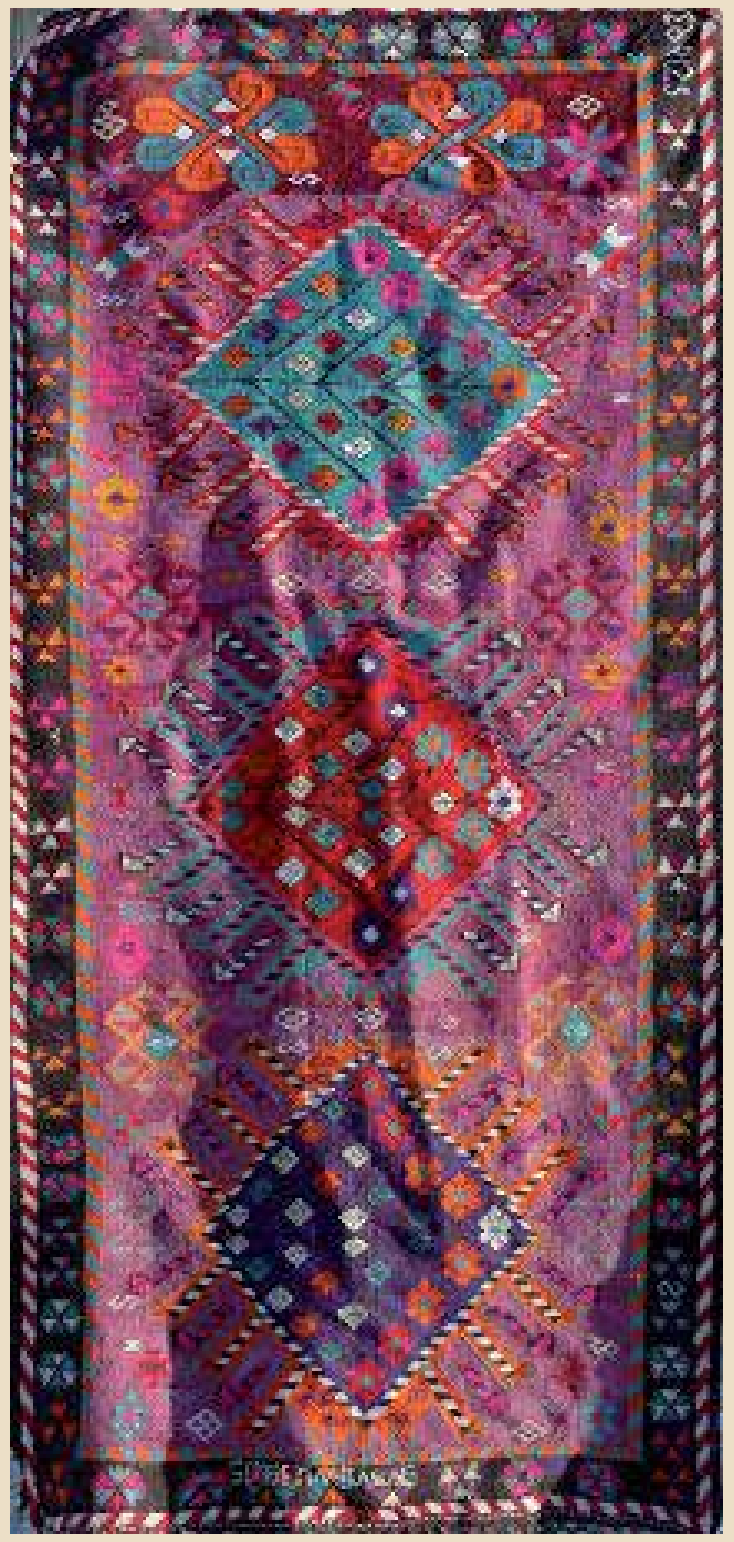

Foto 2 .

Dikdörtgen formlu uzun boyutlu olarak bulunmuş kilim, Posof / Baykent (Vagla) yöresine aittir. $165 \times 345 \mathrm{~cm}$ ebatlarında olan bu kilim dokumasında, geometrik motifler hâkimdir. Eflatun renkli zemini üç bölüme ayrılmış olan kilimin ortası üç göbek madalyonlardan oluşan oz damgası ve bu oz damgalarının içerisi hayat ağa$\mathrm{Cl}$ motifi ile süslenmiştir. Üst köşesinde iki adet çarkıfelek bulunmaktadır. Zemin boşluklarında

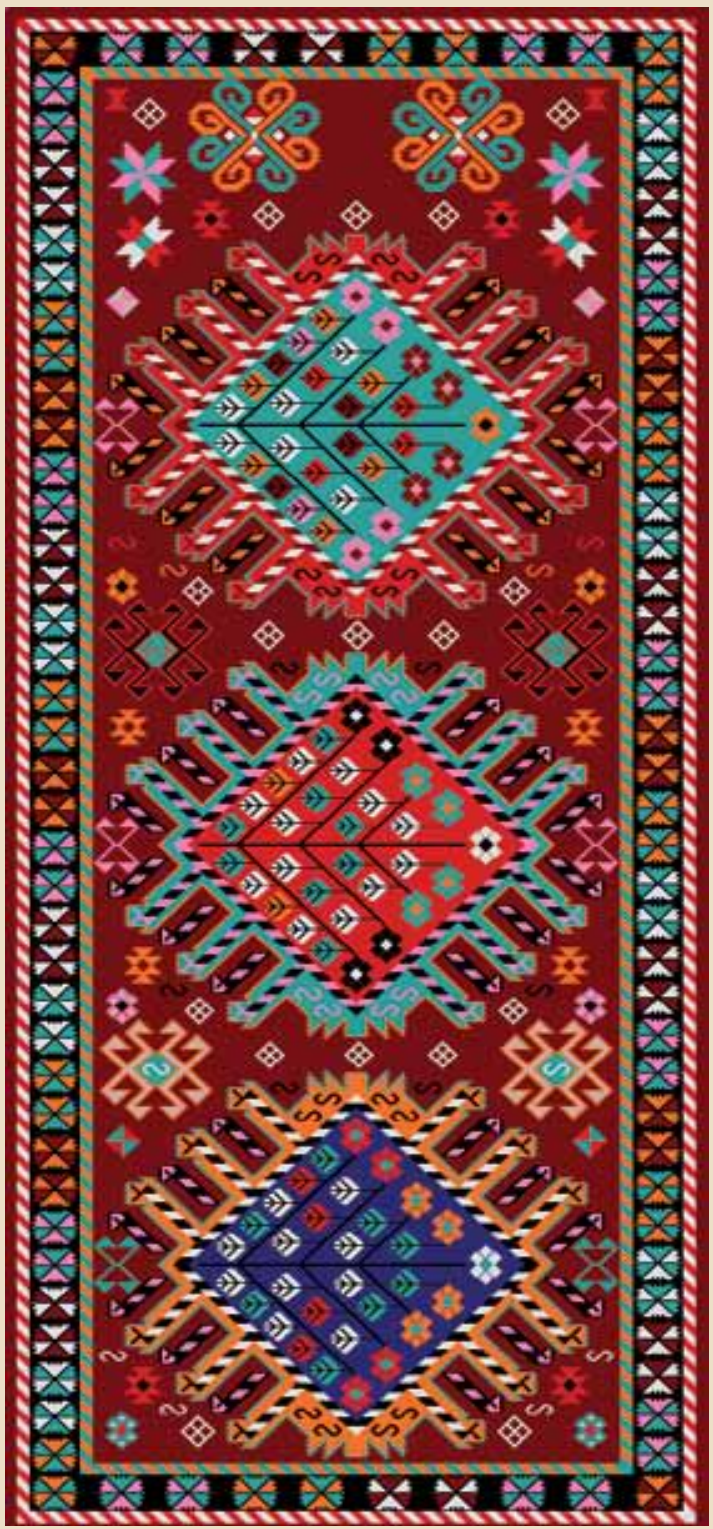

Çizim 2.

çiçek, dolgu motifi olarak kullanılmıştır. Bordür zemininde siyah renk üzerine ardı arda sıralanmış küpe motifi işlenmiştir. Suni ve doğal boya kullanılmıştır. Atkısı ve çözgüsü yün olup, ilikli kilim tekniği uygulanmıştır. 


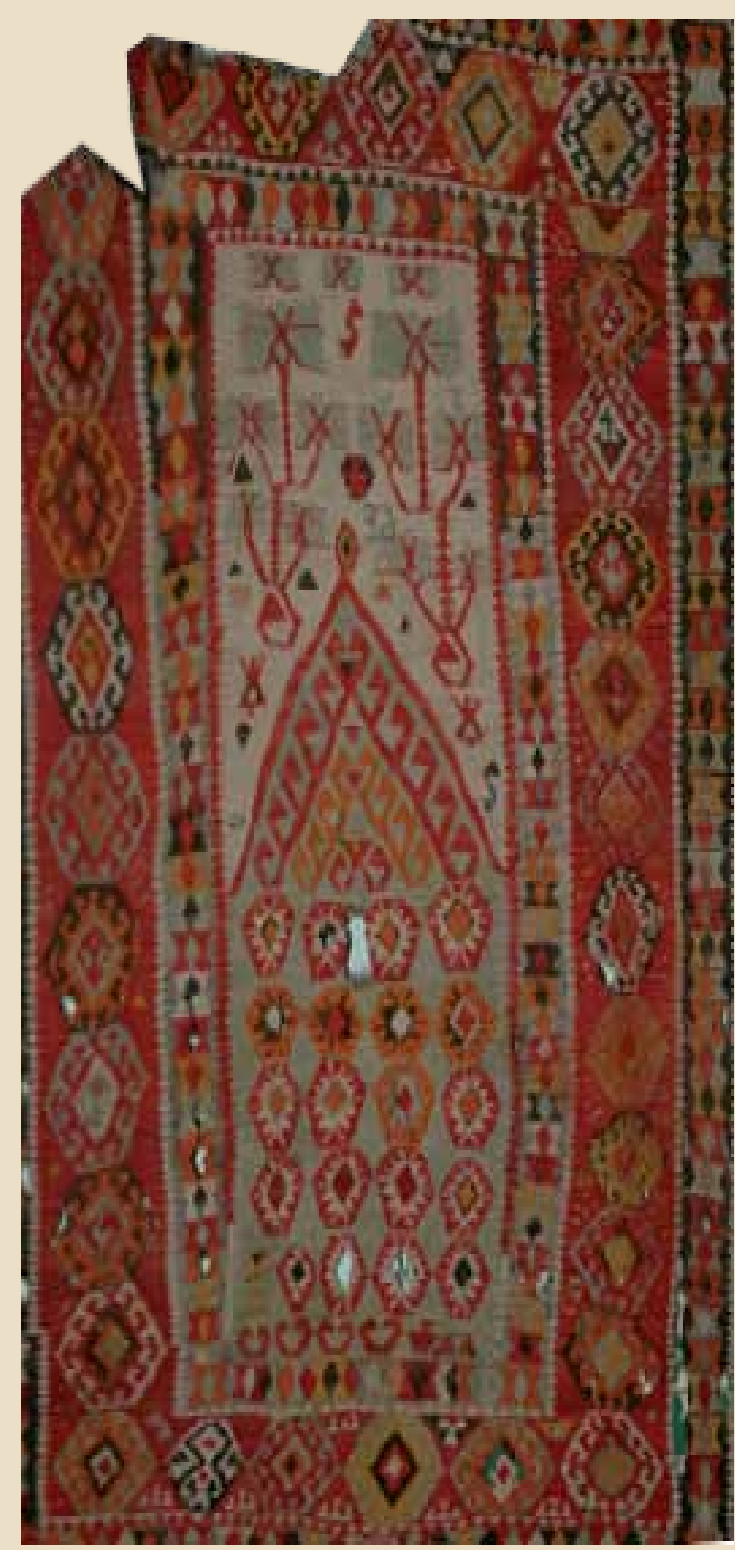

Foto 3.

Dikdörtgen şeklinde olan bu kilim seccade, Posof / Yeniköy camiisinde bulunmaktadır. 110x150 cm ebatlarında olan bu kilim seccade desen ipliği ve çözgüsü yün olup, mihrabın iç kısmı pıtrak motifleriyle doldurulmuştur. Kandil kısmı koçboynuzu ve çengellerle süslenmiştir. Mihrabın dış alınlık kısmında ise hayat ağacı ve ibrik motifi kullanılmıştır. Mihrabın iç zemin kısmı yeşil kırmızı, turuncu kullanılmıştır. Bordür kısmı ise bir geniş iki dar bordürden oluş-

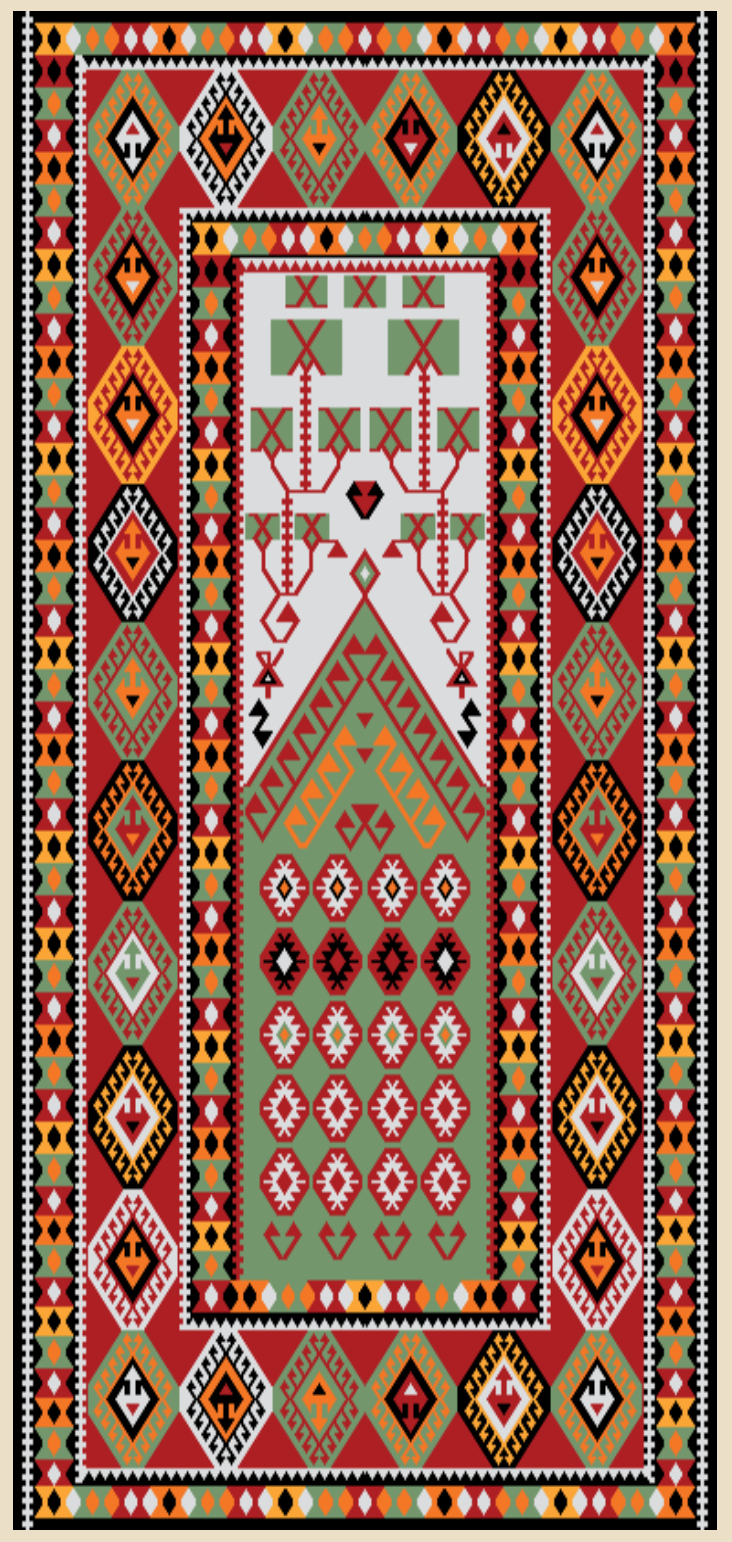

Çizim 3.

muştur. Dar bordürde küpe motifleri yeşil zemin üzerine kullanılmıştır. Geniş bordürde ise kırmızı zemin üzerine ejder motifi işlenmiştir. En diştaki dar bordür ise siyah zemin üzerine diğer dar bordürde olduğu gibi küpe motifleri kullanılmıştır. motifler ikiye bölen üçgen formunda çengel motifi kullanılmıştır. Bu çengel motifinin alt kısmında tekrar eden iki tane daha çengel motifi kullanılmıştır. 


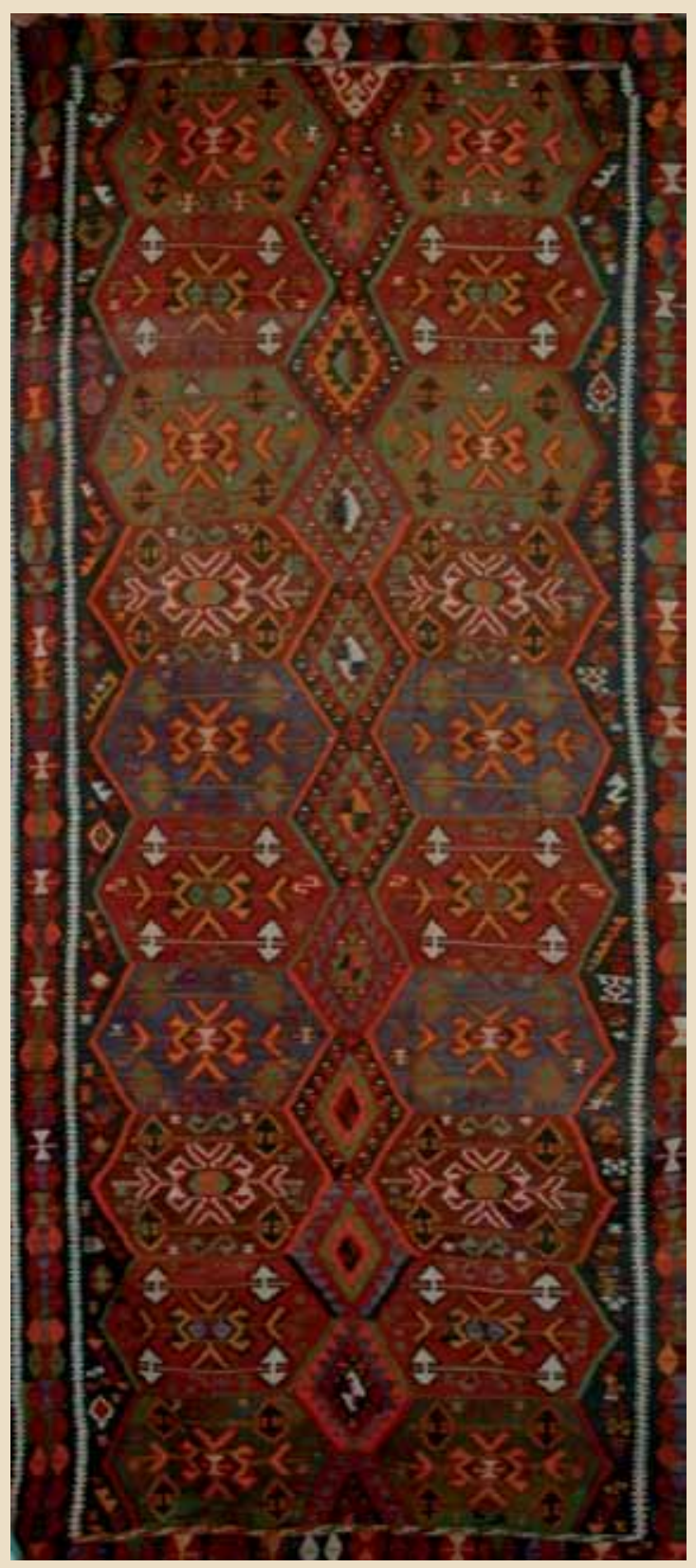

Foto 4.

Uzun dikdörtgen formunda olan kilim Posof / Aşıkzülali köy camisinde bulunmaktadır. $120 \times 380 \mathrm{~cm}$ ebatlarında olup, zemininde birbirine baglantılı sekizgen motiflerin üst üste sıralanarak ve bu sekizgen motiflerinin içerisine iç oguzu ve dışoguzu temsil eden motifler kullanılmıştır. Bordürle zemini ayıran taraklar kullanıl-

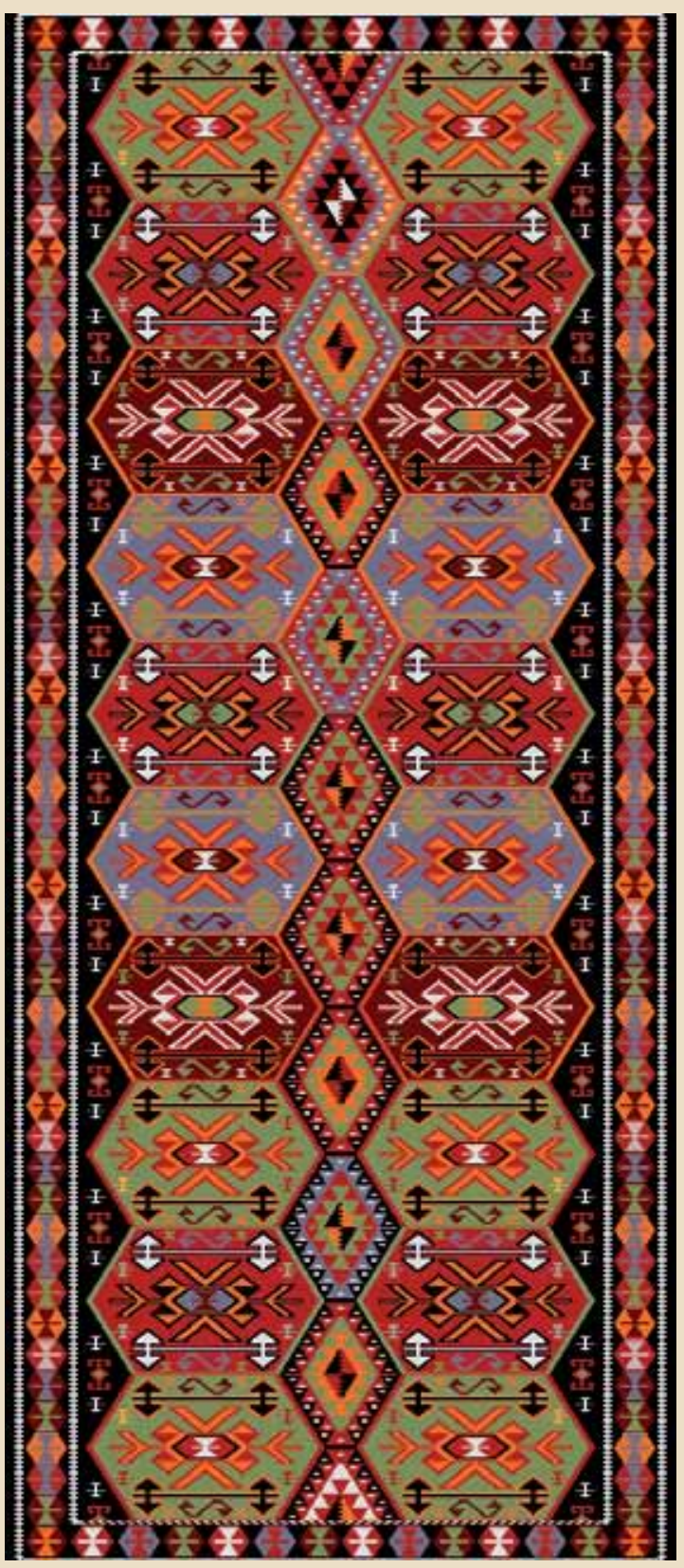

Çizim 4.

mıştır. Bordürde nazar motifi kullanılmıştır. Zemin ve bordürde kullanılan renkler siyah, kırmızı, beyaz, sarı, gri, yeşil renkler hâkimdir. Kimyasal ve doğal boya kullanılmıştır. desen iplikleri yün çözgü iplikleri ise pamuk ipliği kullanılmıştır. 


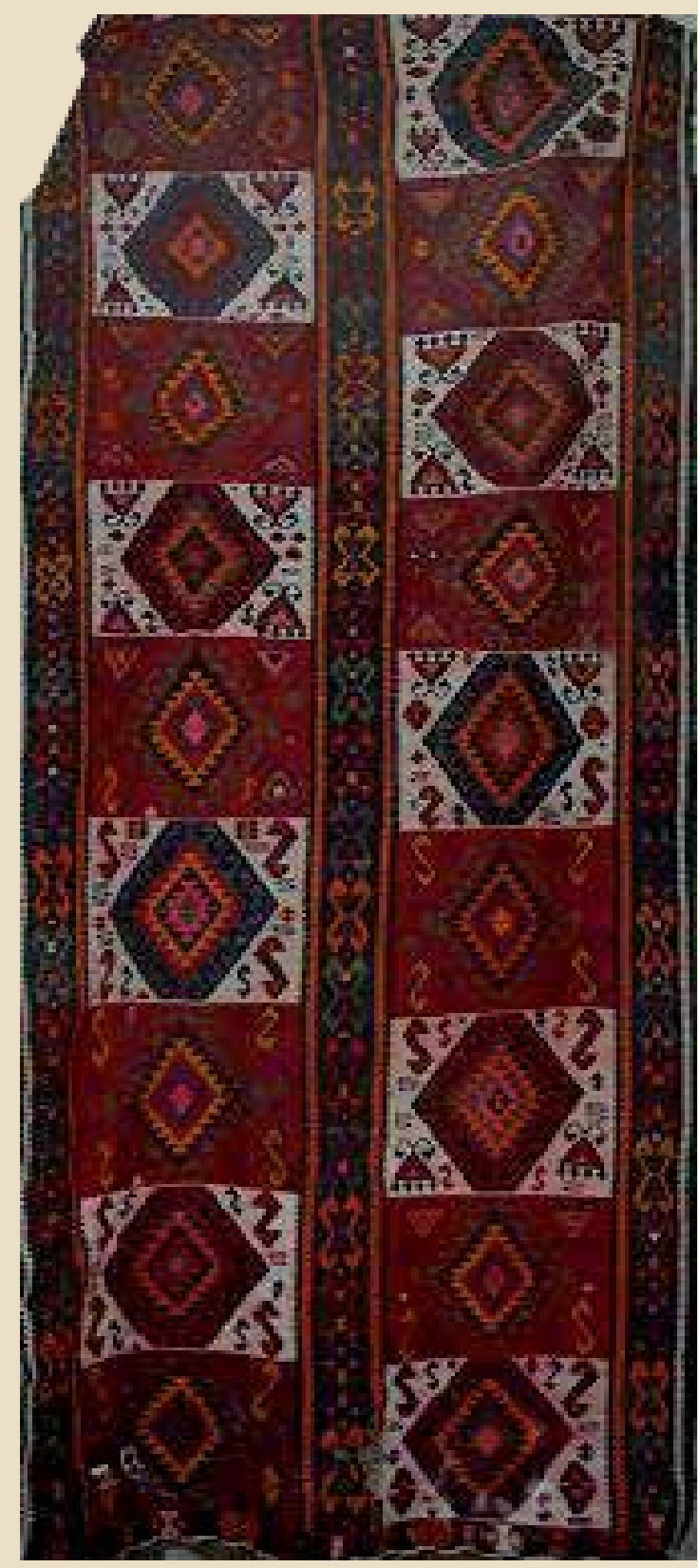

Foto 5.

Dikdörtgen formunda olan bu kilim, Hanak / Avcılar (Kışla Hanak) yöresinde bulunmaktadır. 150x450 cm ebatlarında olup, zemini şeritle ikiye ayrılmış olup zeminde baklava dilimleri ve bu baklavaların içerisine çengel(bereket)motifleri yerleştirilmiştir. Zemini ayıran şerit ve bor-

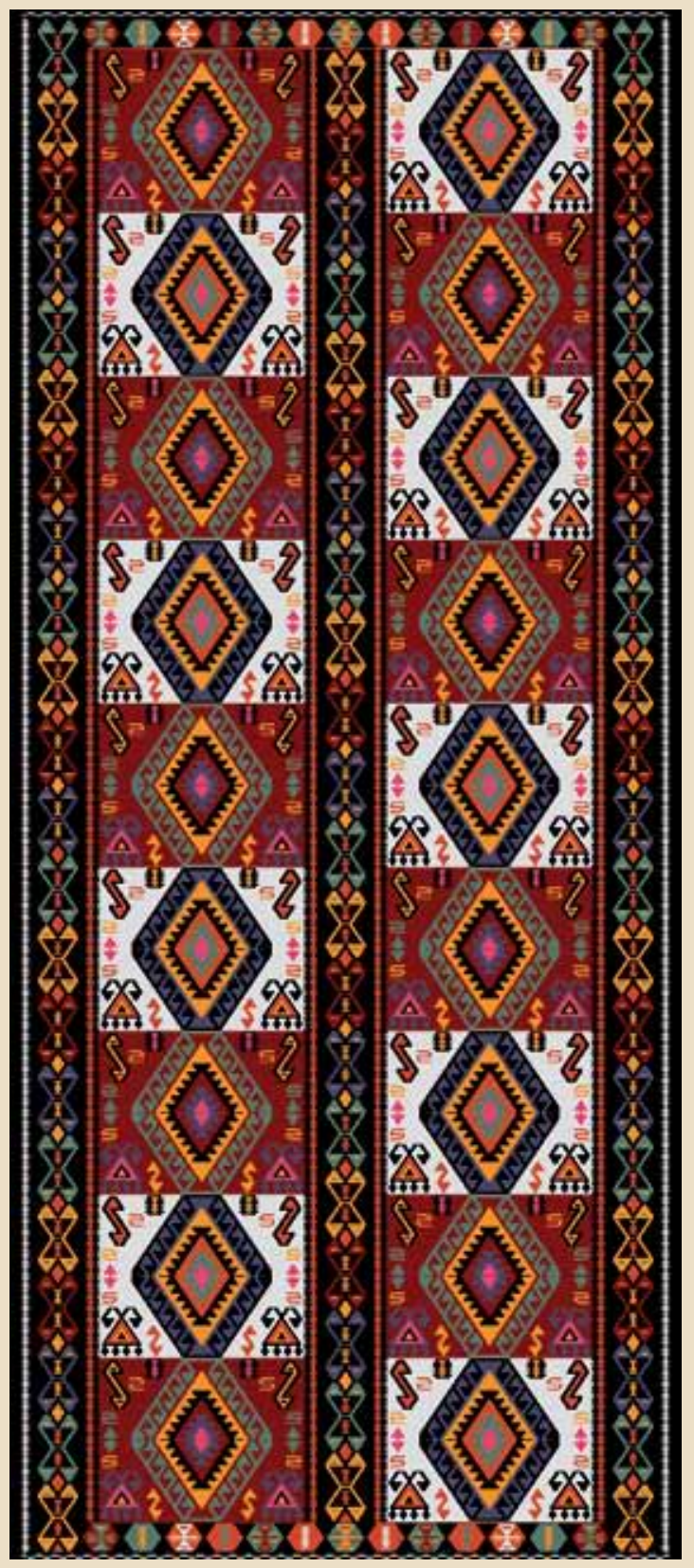

Çizim 5.

dür kısmı taraklarla ayrılmıştır. Bordürde koçboynuzu motifi birbirinden kopmadan bağlantılı bir şekilde yerleştirilmiştir. Desen ipliği ve çözgü yün ipliğinden dokunmuştur. Renk olarak doğal boya olup kırmızı, siyah, yeşil, sarı, beyaz renkler kullanılmıştır. 


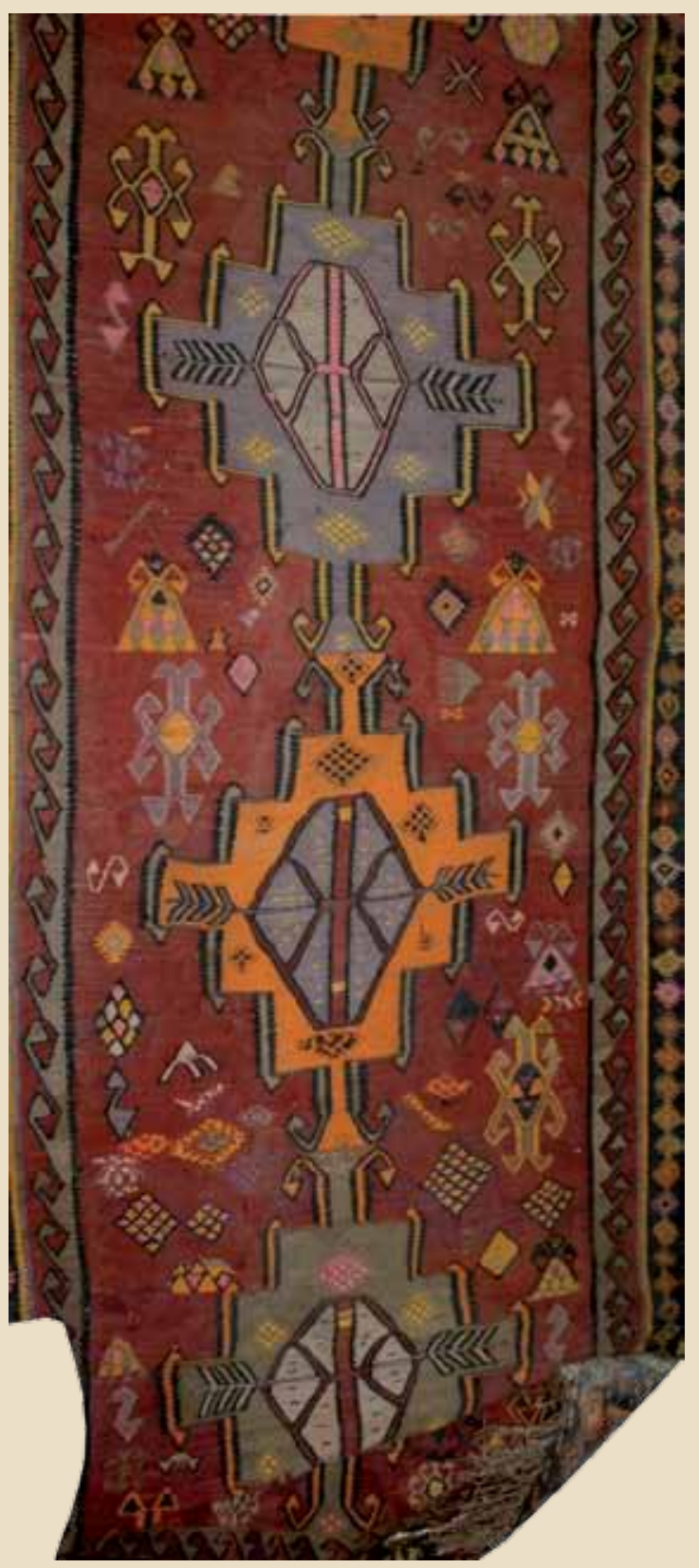

Foto 6.

Dikdörtgen formunda olan kilim Çıldır / Akçakale köyü sakinlerinden olan Tahsin Sarıçayır'ın evinde bulunmaktadır. 160x400 cm ebatlarındadır. Yaklaşık 40 yıllık bir geçmişe sahip olduğunu ifade etmektedir. Bu dokumanın zemini dört adet madalyon şeklinde ejder motifini simgeleyen motif yer almaktadır. Göbeklerin içerisinde oğuz damgasını sembolize eden motif kullanılmıştır. Göbeğin dışında kalan zeminde ise koçboynuzu, eli belinde, çakmak, sekiz kollu yıldız,

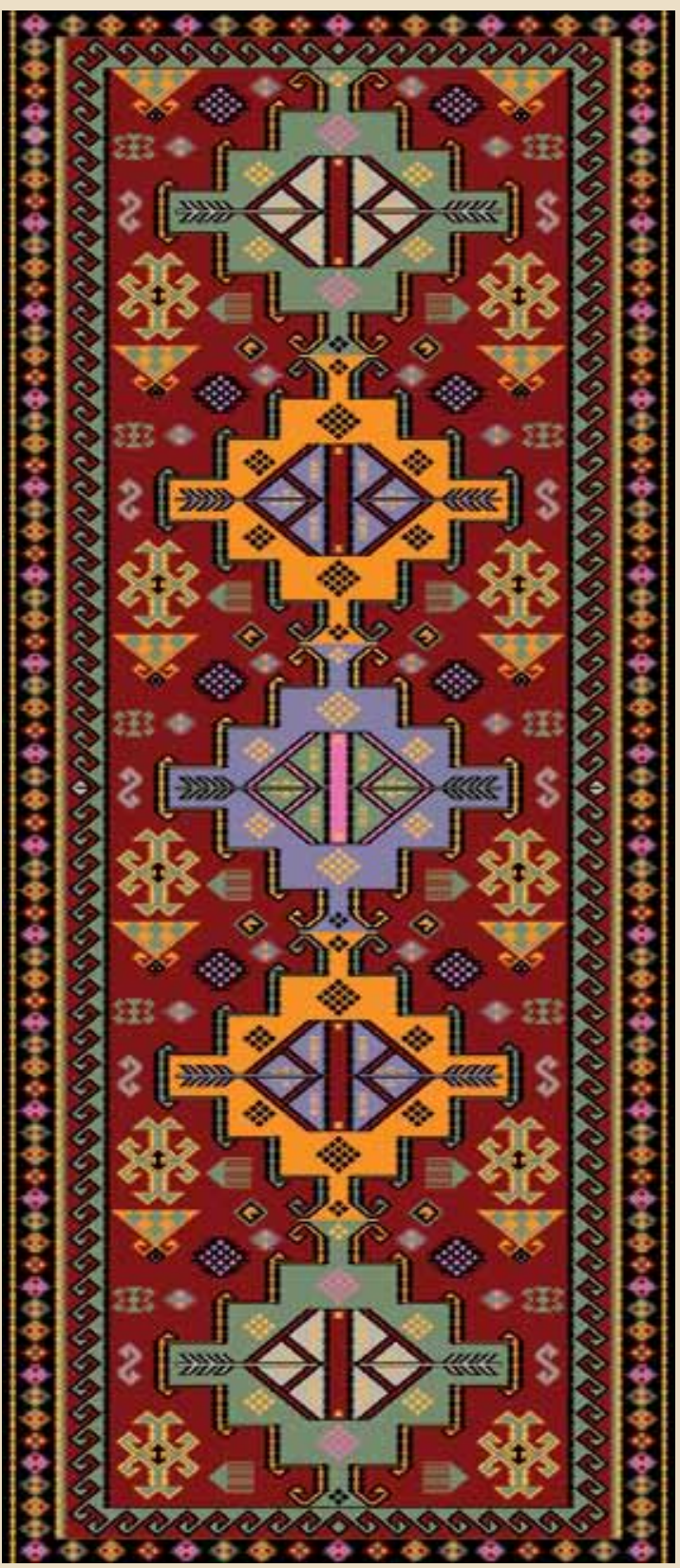

Çizim 6.

küpe, kuş ve baklava dilimleri yerleştirilmiştir. Zeminden hemen sonra gelen bordürde suyolu, en dıştaki bordürde ise küçük baklava dilimleri birbiriyle bağlantılı şekilde sıralanmıştır. Kırmızı renk yoğunlukta olmasına rağmen bunun yanı sıra sarı, yeşil, gri, mor, siyah ve turuncu renkler kullanılmıştır. desen iplikleri yün çözgü ipliği ise pamuk kullanılmıştır. boyama kimyasal ve doğal boya kullanılmıştır. 


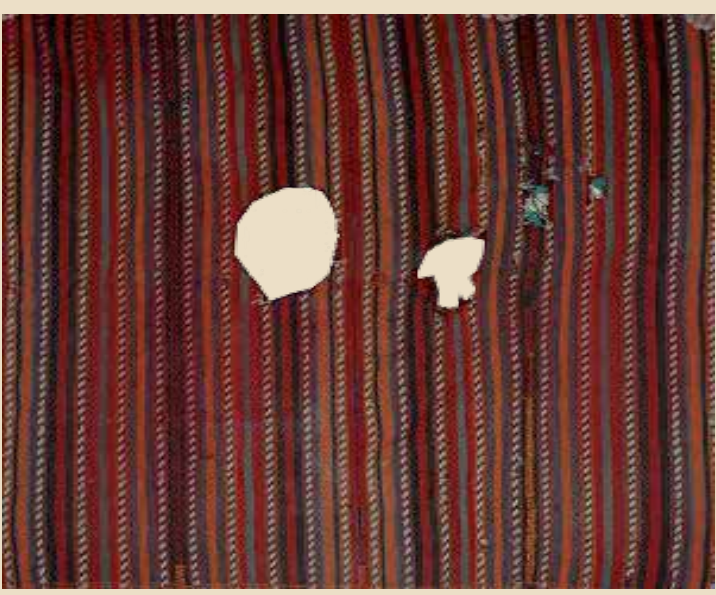

Foto 7.

Dikdörtgen formunda olan bu cicim Posof / Yeniköy camiinde bulunmaktadır. 140x160 cm ebatlarında olup, zemini tamamen ince şeritler-

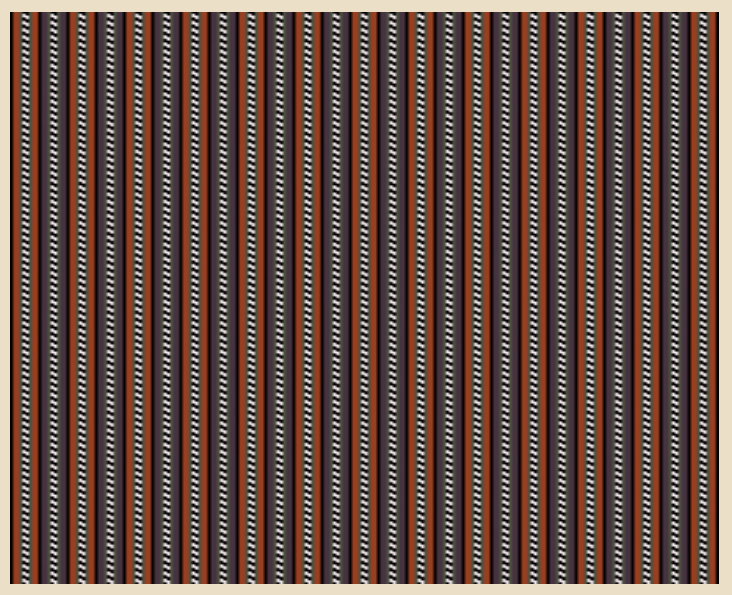

Çizim 7

den oluşmakta olup ince şeritlerin içerisinde sıçandişi motifi kullanılmıştır. Sarı, kırmızı, siyah, renkler hâkimdir. Malzeme yün kullanılmıştır.

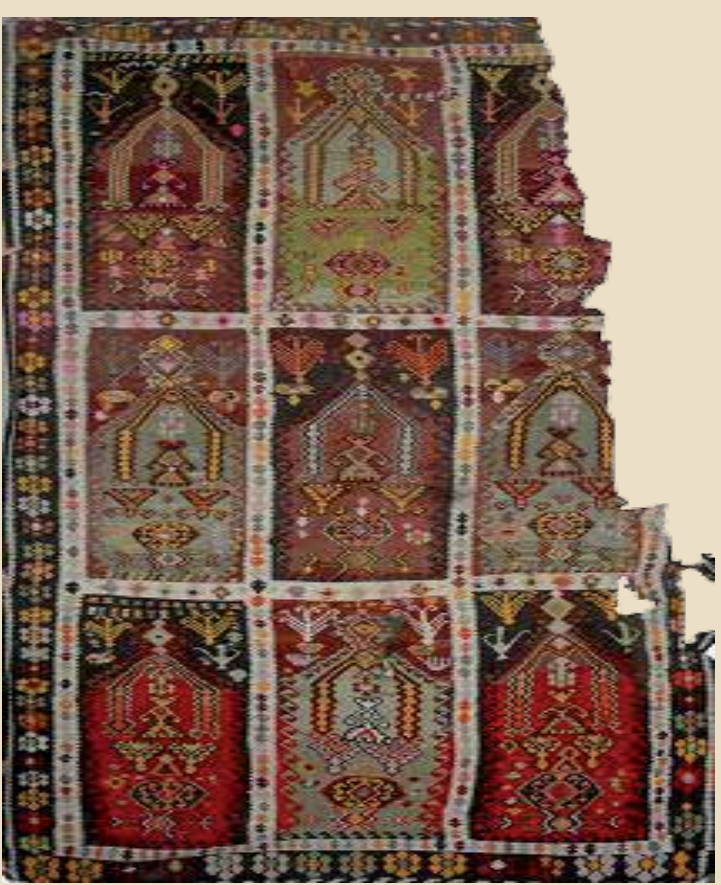

Foto 8.

Dikdörtgen formunda olan bu seccade kilim, Posof /Alköy camisinde bulunmaktadır. Posof yöresine ait bir düz dokumadır. 155x340 cm ebatlarında olup, zemini dokuz eşit parçaya ayrılmış olup yan yana ve üst üste mihraplar yerleştirilmiştir. Bu mihraplar içerisinde sonsuzluğu ve öldükten sonrada hayatın devam edeceğini simgeleyen hayat ağacı, doğurganlığı ifade eden elibelinde motifi ve kandil motifleri yer almaktadır. Mihrapların dışında kalan

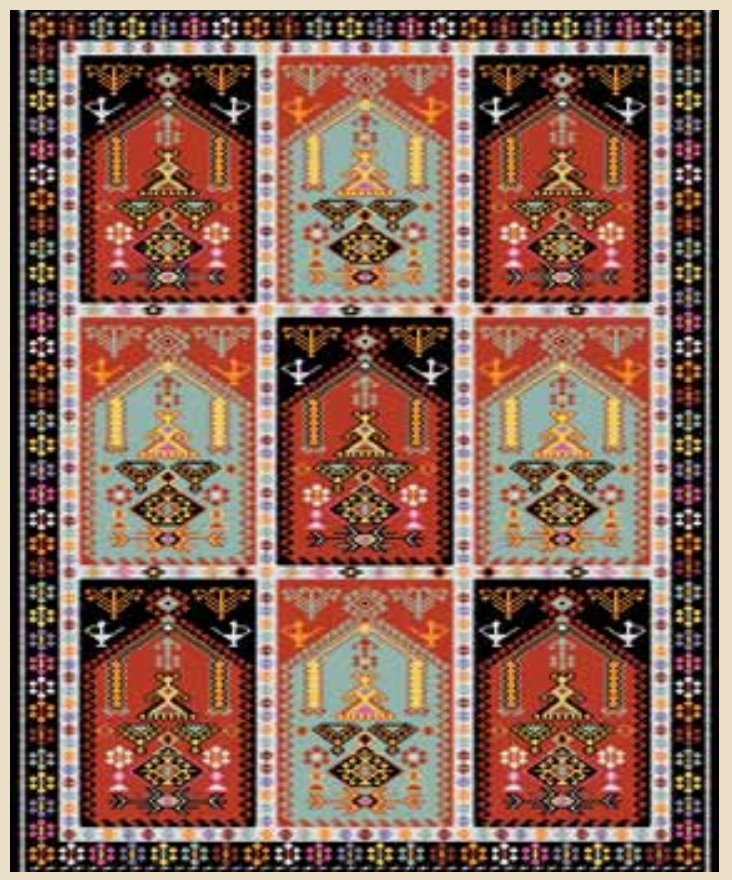

Çizim 8.

ve zeminde yer alan temizliği simgeleyen ibrik motifi ve zeminle mihrap içini ayıran çengel motifleri yer almaktadır. En dışta kalan bordürde ise çiçek motifleri yer almaktadır ve şeritler taraklarla birbirinden ayrılmıştır. Şeritlerin içerisinde mantar motifi kullanılmıştır. Kullanılan renkler doğal boya olup kırmızı ağırlıkta olup sırasıyla beyaz, yeşil siyah, turuncu ve sarı renkler kullanılmıştır. Desen ipi ve çözgüsü yünden elde edilmiş iplikten yapılmıştır. 


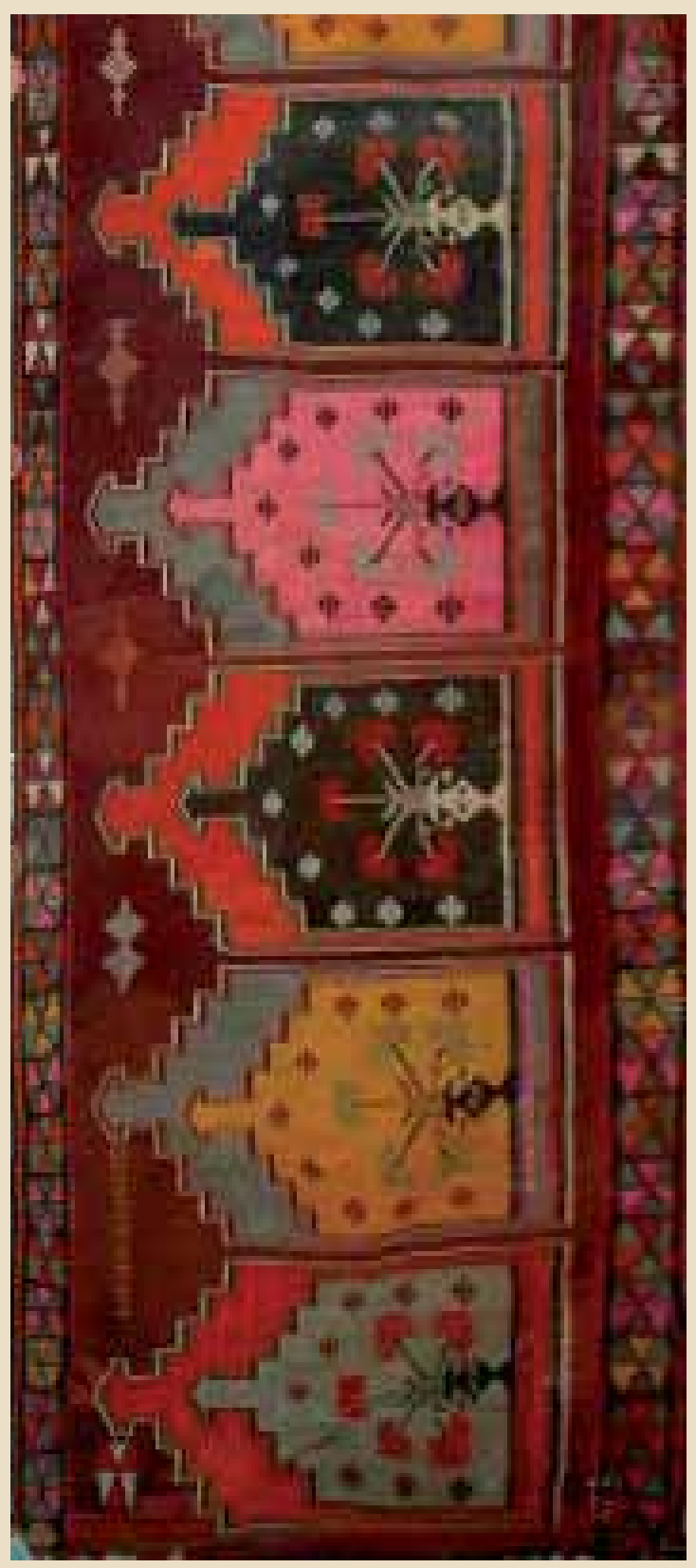

Foto 9.

Dikdörtgen formunda olan bu seccade kilim, Posof / Aşıkzülali köy camisinde bulunmaktadır. Bu düz dokuma mihraplı kilim 155x435 cm ebatlarında olup, zemini enine yedi mihraptan oluşmaktadır. Mihrapların her iç içe geçmiş çift mihraplı olup ikinci mihrabın zemininde vazoda karanfiller kullanılmıştır. Zeminle bordür taraklarla

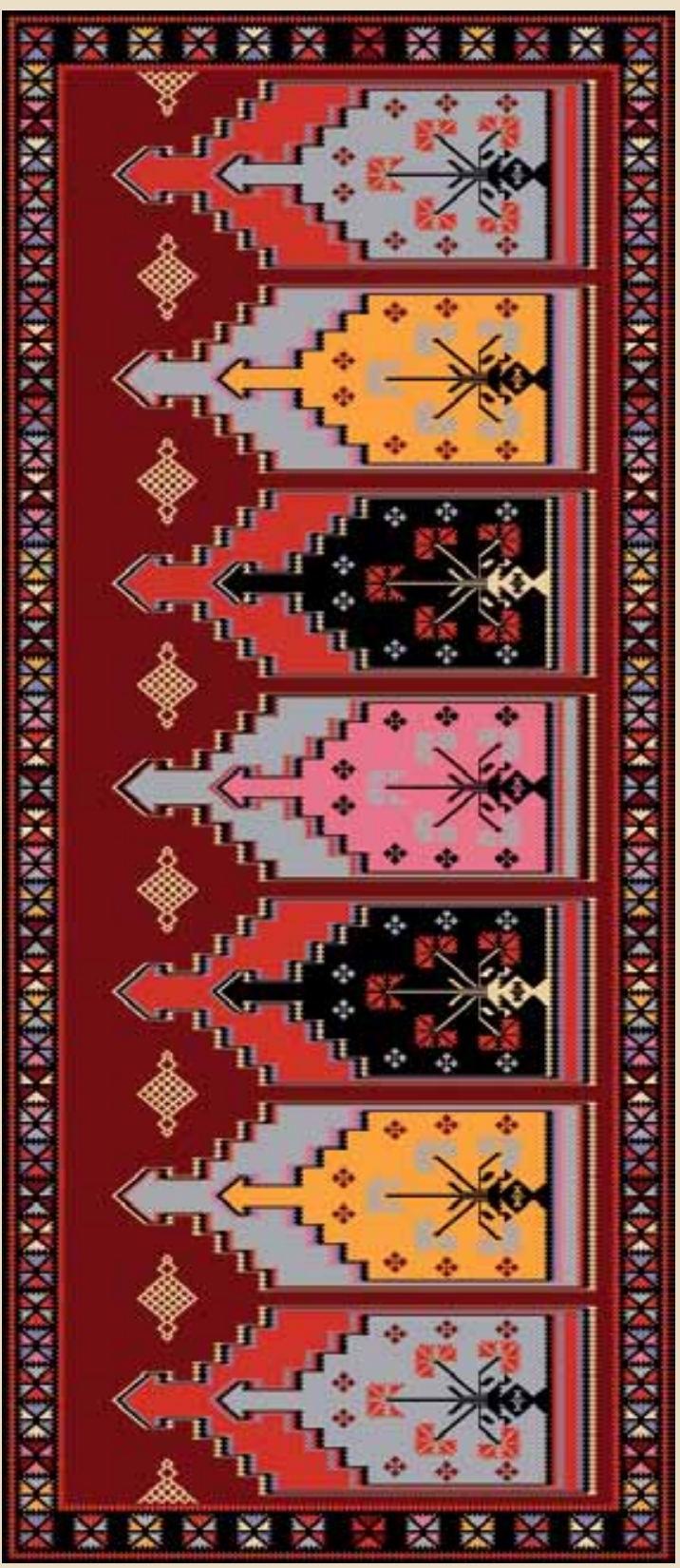

Çizim 9.

birbirinden ayrılmış olup bordürde muska motifi sıralanmıştır. Kullanılan renklere baktığımız zaman bordo, sarı, kırmızı, pembe, gri,yeşil, turun$\mathrm{cu}$, mor ve siyah renkler kullanılmıştır. desen iplikleri yün çözgü ipliği ise pamuk'tan elde edilmiş olup kimyasal ve doğal boya aynı anda kullanılmıştır. 


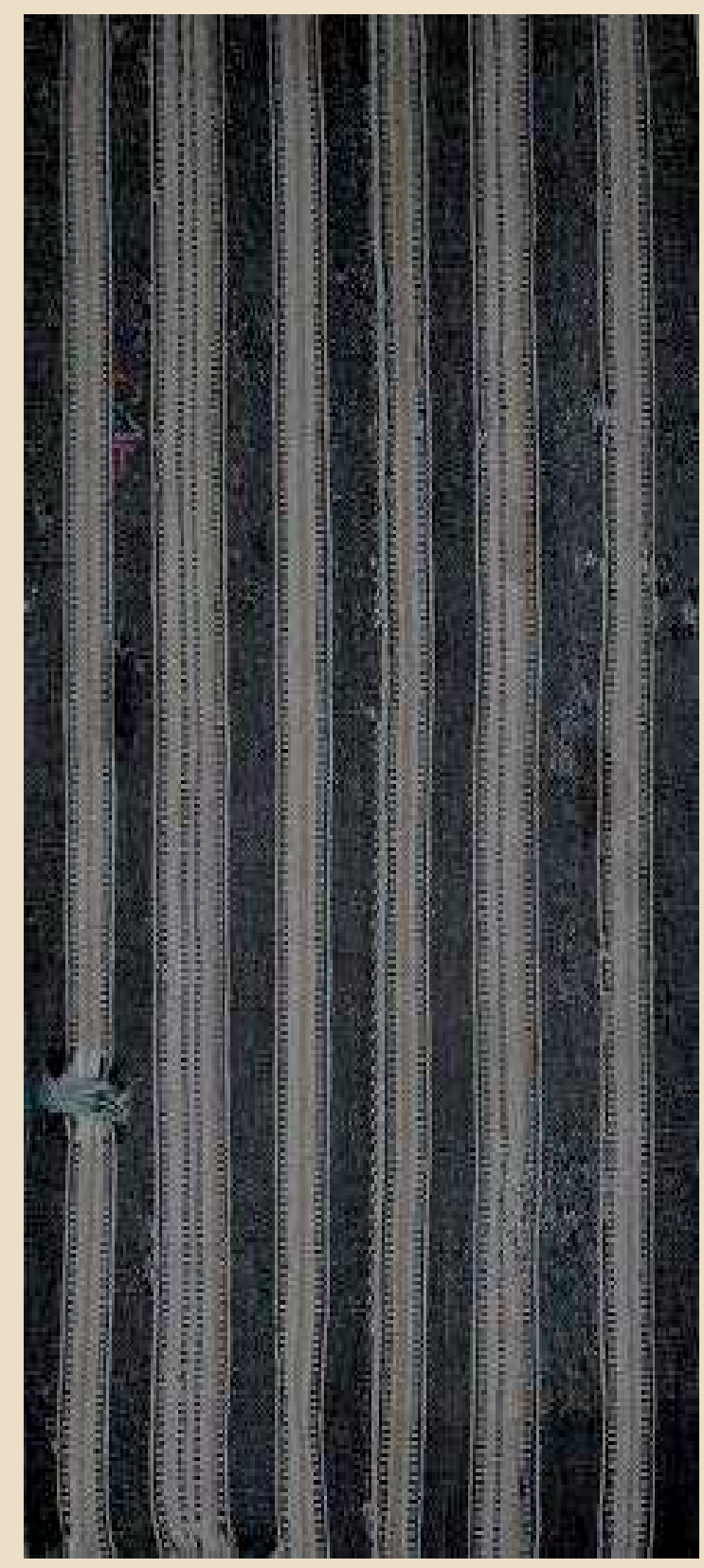

Foto 10.

Dikdörtgen formunda olan bu cicim dokuması Posof / Yeniköy camisinde bulunmaktadır. 130x220 cm ebatlarında, zemini tamamen şeritlerden oluşmakta olup siyah ve gri renkler hâkimdir. Malzeme doğal yün olup herhangi bir boya maddesi kullanılmamaktadır.

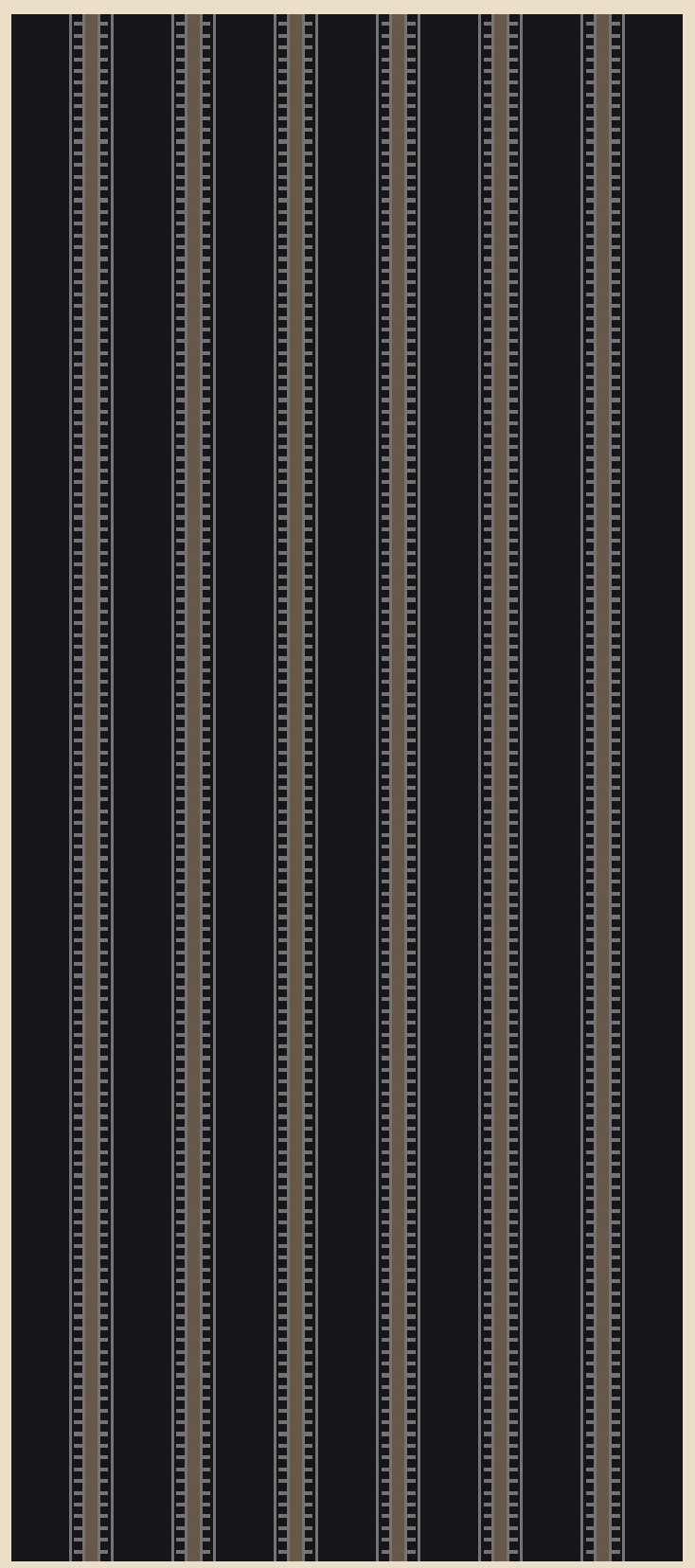

Çizim 10 


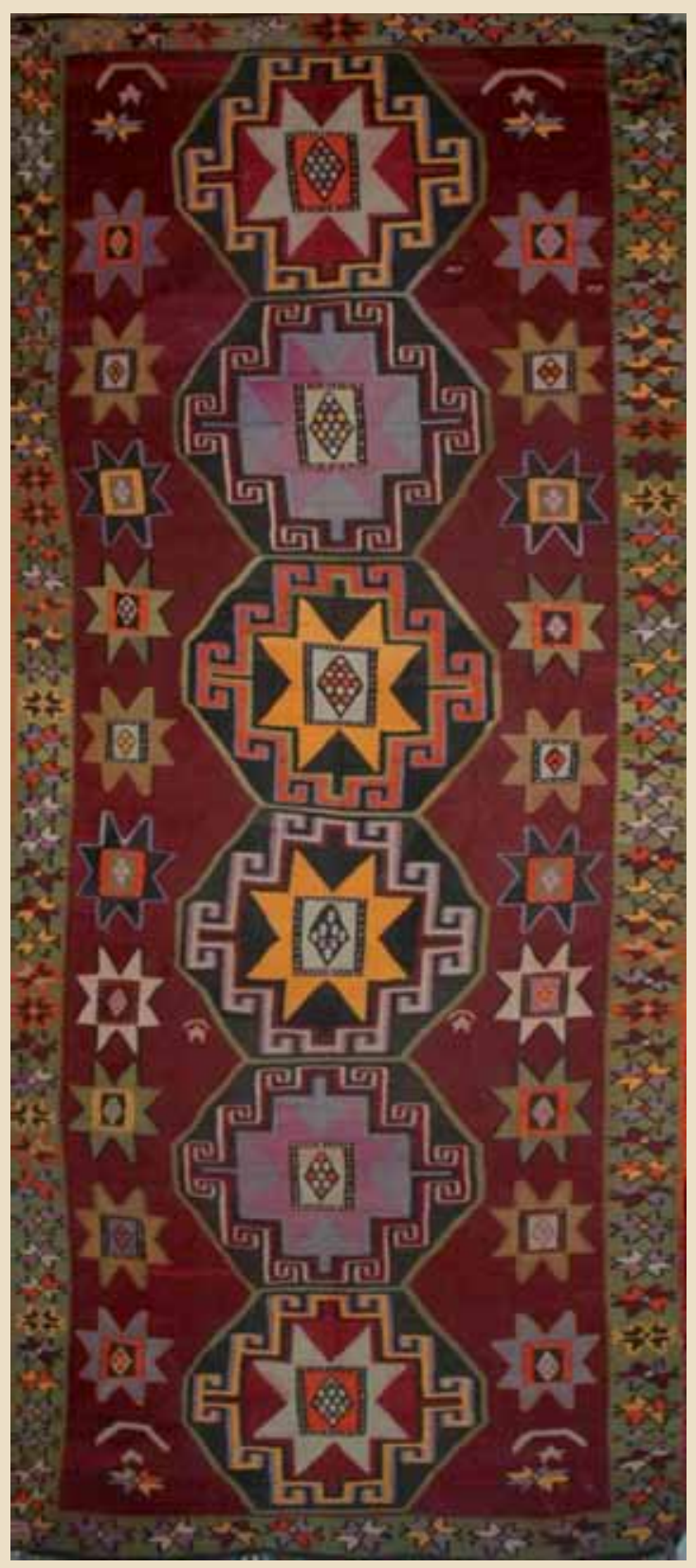

Foto 11

Dikdörtgen formunda olan bu kilim, Posof merkeze ait bir dokumadır. 170x430 ebatlarında olup, zemini birbirinden kopmayan altıgenler göbek görünümü uyandırarak zemine yerleştirilmiştir. Altıgenlerin içerisine geometrik motifler ve bu geometrik motiflerin içerisine sekiz kollu yıldızlar ve sekiz kollu yıldızların içerisine bereket motifleri yerleştirilmiştir. Göbeğin dışın-

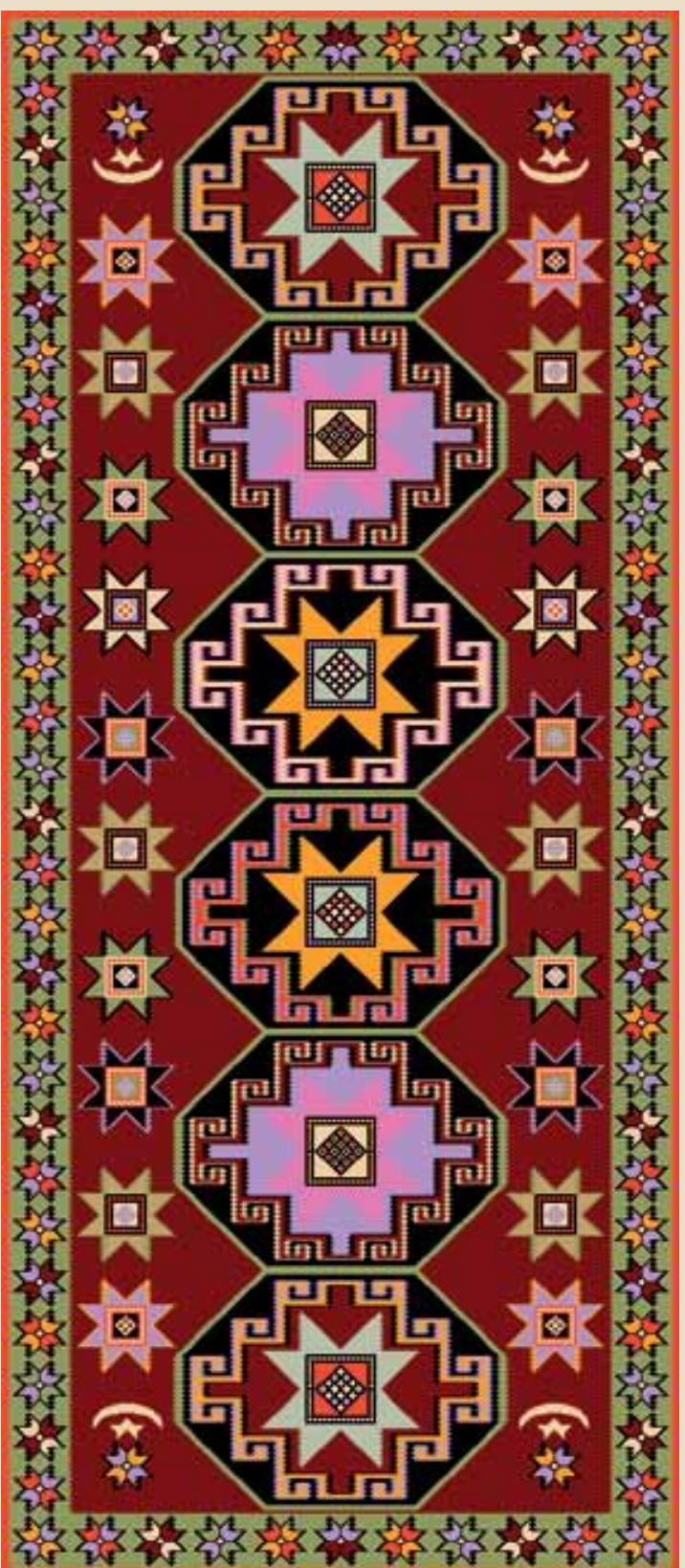

Çizim 11.

da kalan zeminde sekiz kollu yıldızlar ve zeminin köşelerinde bayrağımızı simgeleyen ay yıldız yer almaktadır. Zemin ile bordür tarakla birbirinden ayrılmıștır. Siyah, kırmızı, sarı, beyaz, turun$\mathrm{cu}$, yeşil renkler kullanılmıştır. Atkı ve çözgüsü yün olup iplikler doğal boya ve bitkisel boya aynı anda kullanılmıştır. 


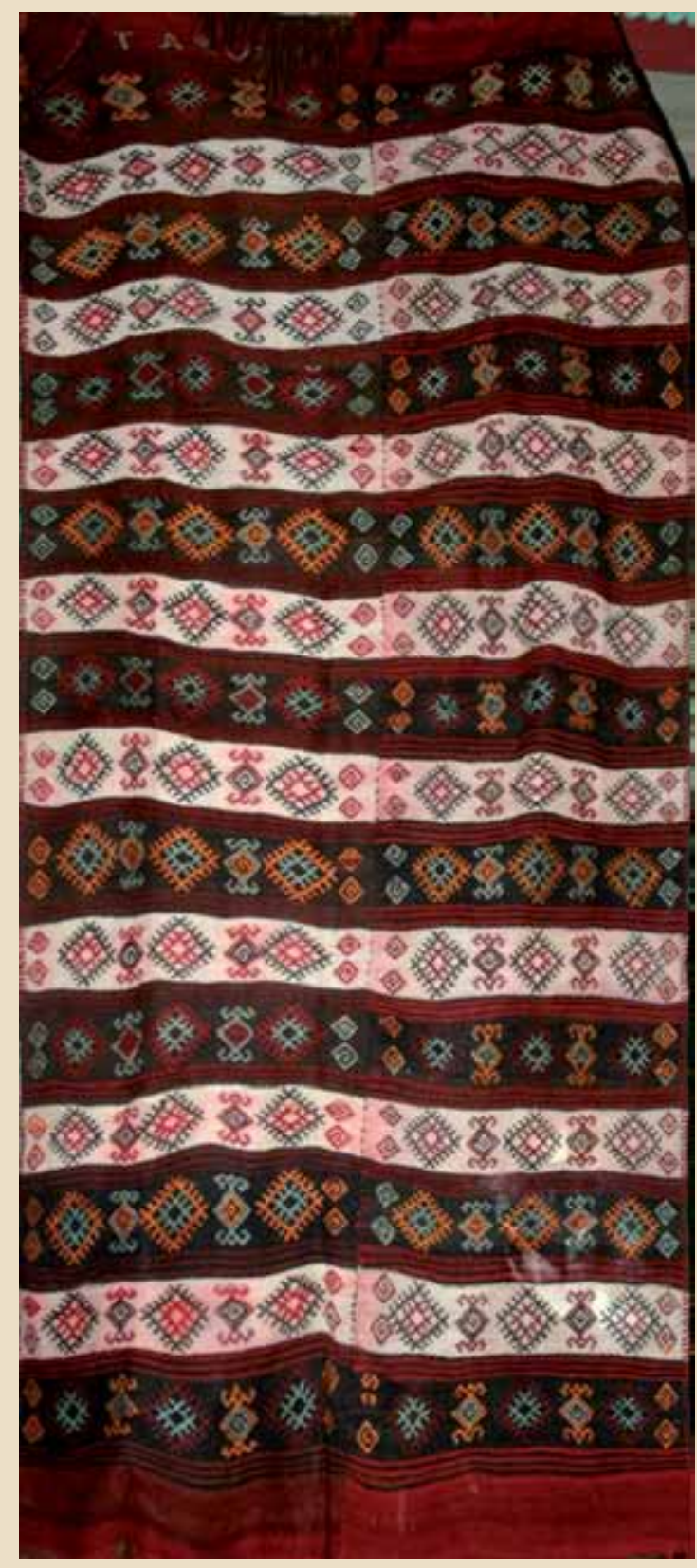

Foto 12.

Dikdörtgen formunda olan cicim Hanak / Avcılar (Kışla Hanak) köyünde köy camisinde bulunmaktadır. İki şak olarak dokunmuş olup, birbirine dikilmiştir. Bordür bulunmamaktadır. Zemini birbirine pareler şekilde şeritlerden oluş-

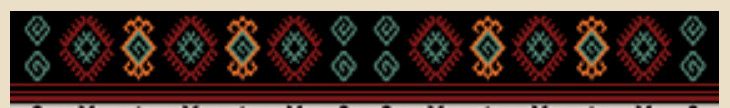

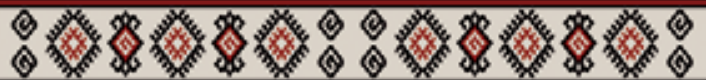

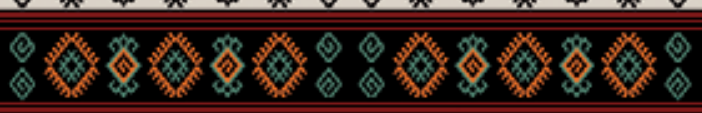

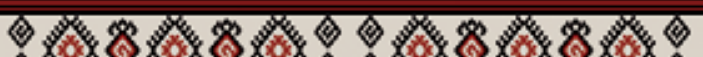

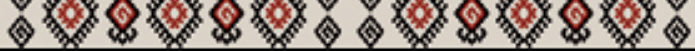

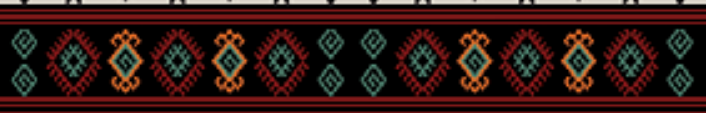

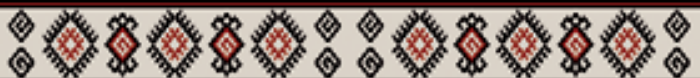

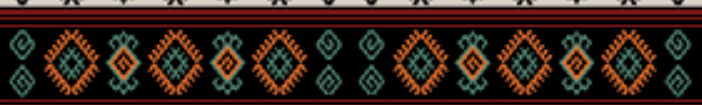
- 128\%

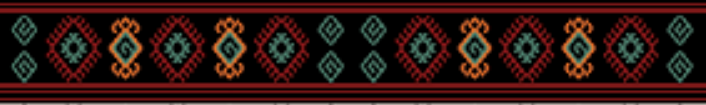

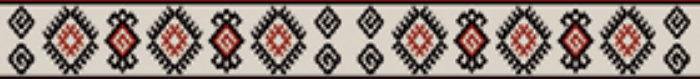

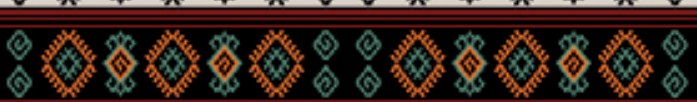
- 158

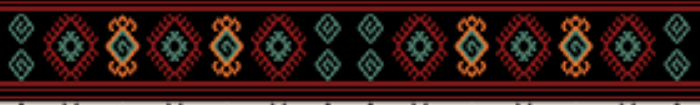

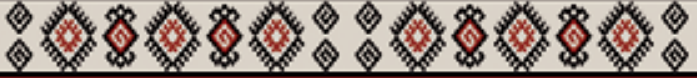

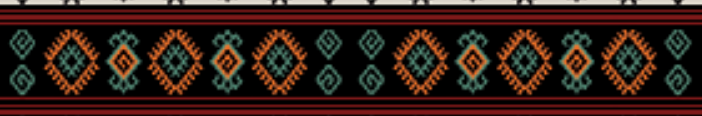

- 1 1

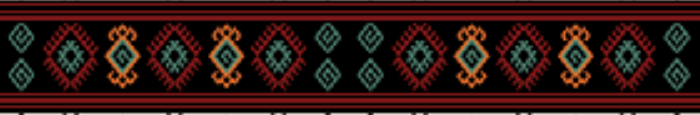

- 18\%

Çizim 12.

maktadır. Bu şeritlerin içerisi pıtrak ve eli belinde motiflerden oluşmaktadır. Kırmızı, siyah, beyaz, yeşil ve sarı renkler kullanılmıştır. Atkı ve çözgüsü yün boyama olarak da kimyasal ve doğal boya aynı anda kullanılmıştır. 


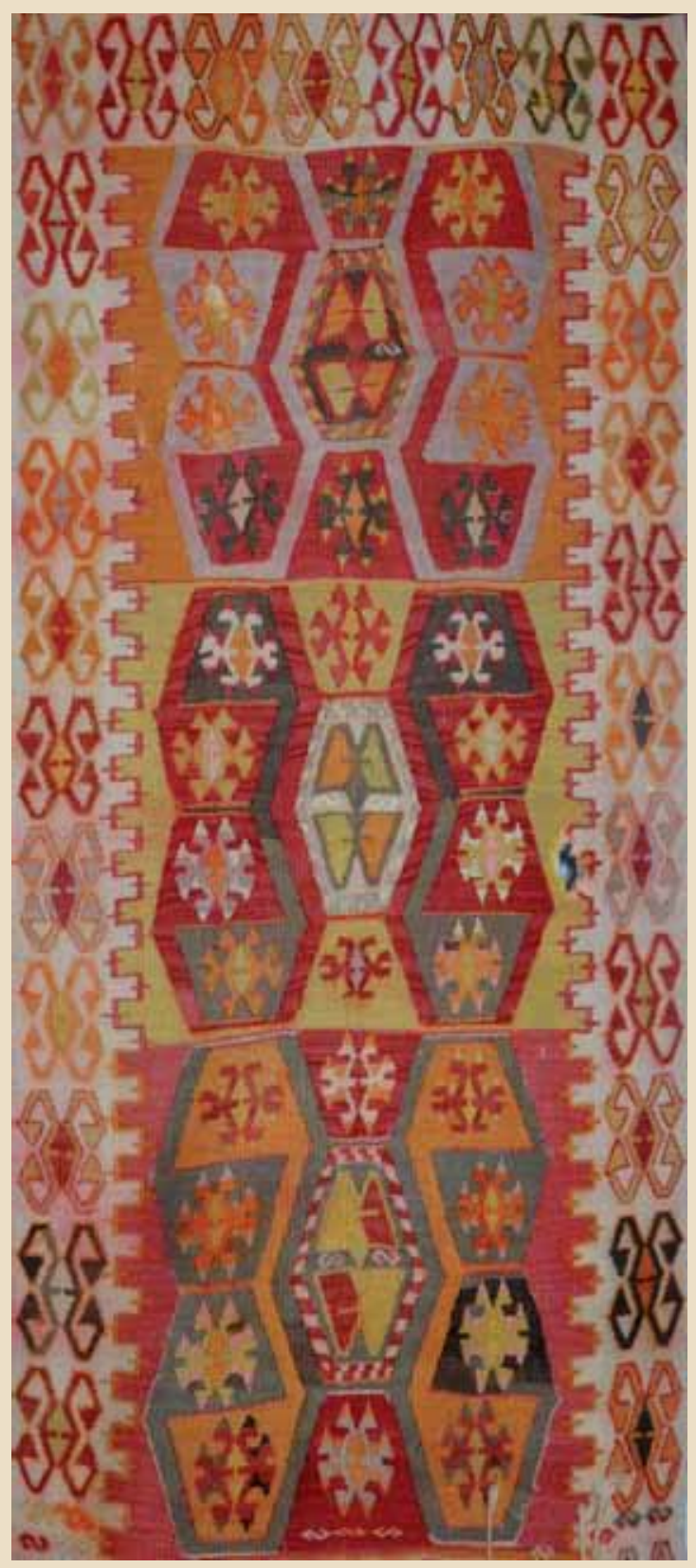

Foto 13

Dikdörtgen formunda olan kilim Posof merkez camii'de bulunmaktadır. Zemini birbirine bağlı madalyon şeklinde üç büyük koçboynuzu kullanılmıştır. Bu madalyonların içinde kurtağzı motifi kullanılmıştır. Zemin ve bordürü ayıran tarak kullanılmıştır. Bordürde tekrar eden koç-

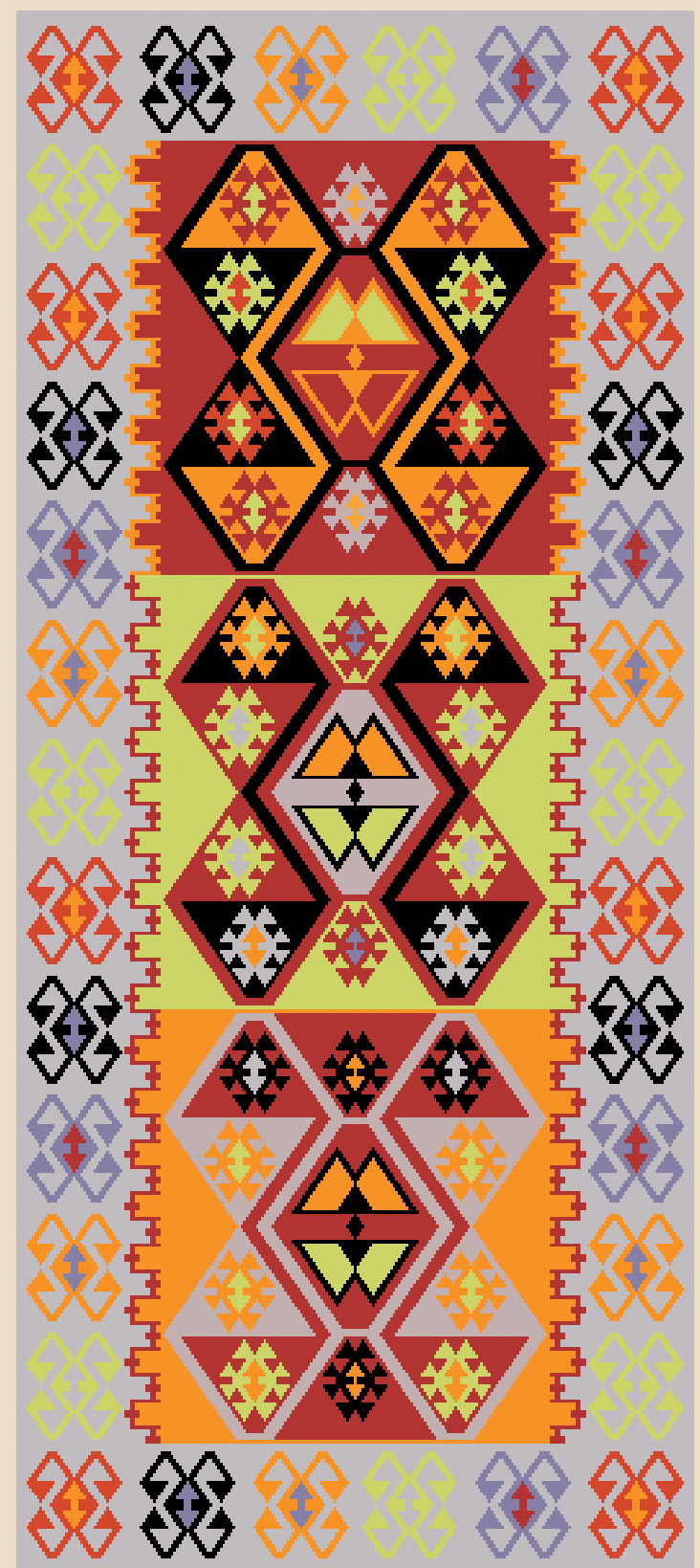

Çizim 13.

boynuzu motifi ardı arda yerleştirilmiştir. Kırmızı, turuncu, yeşil, gri, siyah ve beyaz renkler kullanılmıştır. Atkı yün çözgü ise pamuk olarak kullanılmıştır. İplikler kimyasal ve doğal boya birlikte kullanıldığı tespit edilmiştir. 


\section{Sonuç}

Ardahan ve yöresi, geçmişten günümüze değin yaşatılan önemli dokuma merkezlerini bünyesinde barındırmaktadır. Ardahan ve yöresi yerleşik hayat kuran ve kökleri Orta Asya'ya dayanan Türk kavimlerinin dokuma kültürünü devam ettirdikleri görülmektedir.

Araştırma sahamız olan Ardahan il merkezi Posof, Çıldır, Hanak, Damal, Göle ve bu ilçelere bağ lı köylerde bulunan örneklerde Anadolu'nun diğer bölgelerindeki örneklerle ortak özelliklerin yanı sıra yöreye has özellikler de görülmektedir.

Düz dokumalar kompozisyon motif ve renk özelliklerine göre;

Posof diğer ilçelere göre daha kapsamlı olup, motif ve desenler çok zengin görünümlü kompozisyona sahiptir. Damal ilçesi dokumaların yanı sıra diğer el sanatlarını da geliştirmişlerdir. Çıldır ve Hanak'ta eskiden yapılmış olmasına rağmen günümüzde tamamen yok olmuştur. Mevcut düz dokumalarda eskiden kalma ya da başka yerlerden gelin alma sonucu çeyizlerinde getirmeleri ya da hediyeleşme sonucu bulunmaktadir.

Ardahan merkezde düz dokumadan ziyade halı atölyeleri mevcut olup yine merkeze bağlı köylerinde ise tamamen yok olmuştur. Mevcut olan düz dokumalar ise eskiden kalmadır.

Ardahan ve yöresinde bulunan düz dokumalar, tek şak veya daha fazla şak olarak dokunup, sonradan birleştirilmiştir. Dokumalarda kullanılan yünler, evlerde el eğirmesi ile elde edilir ya da fabrikalardan alınır.

Araştırma sahamızda, doğal ve bitkisel boyalardan renk elde edilmesi 20- 30 yıl öncesine kadar yapılırken, günümüzde unutulmaya yüz tutmuştur. Son yıllarda bunun yerini kimyasal boyalarla boyanmış iplikler almıştır.

Ardahan ve yöresinde, doğal boya olarak sütleğen, nar kabuğu, mazı, sarı muhabbet çiçeği, sarı, papatya, ceviz kabuğu, çivit otu, kök boya, soğan kabuğu gibi bitkisel boyalar kullanılır.

Ardahan ve yöresi düz dokumalarının kompozisyonlarında geometrik motifler hâkimdir. Renk ve kompozisyon olarak Anadolu'da görülen özelikleri burada da görmekteyiz.

Araştırma sahamızdaki düz dokumalarında kullanılan motifleri şu şekilde sıralayabiliriz; Sembolik, geometrik, hayvansal, bitkisel, damga / imler ve yazı tipi motifi olarak sıralaya biliriz.

Ardahan ve yöresinde en çok kullanılan motifler eli belinde koçboynuzu, yıldız, kurtağzı, bereket, pıtrak, bukağı, muska, el, parmak, tarak, suyolu, küpe, saç bağı motiflerini sayabiliriz.

Düz dokumalarda koyu tonlar hâkimdir. Kahverengi, beyaz, siyah renkler yoğunluktadır. Genel ola- rak 'kırmızı, siyah, beyaz, kirli sarı, lacivert, yeşil, kahverengi, turuncu, mavi' renkler görülür. Beyaz, kahverengi, siyah renkli yünler saf olarak kullanılır. Ardahan ve yöresinde görülen kırmızı koyu tonludur. Doğal boya ile suni boya birlikte kullanılmıştır. İklim özelliğinden dolayı açık tonlar pek tercih edilmemektedir.

Ardahan ve yöresinde dokunan kilimlerin kökeni Orta Asya'ya kadar uzanmaktadır. Geleneksel Türk dokuma sanatının önemli örneklerinin üretildiği bu bölgede son yıllarda kilim dokumacılığının azaldığı ve bırakılma noktasına geldiği görülmektedir. Bu sanatın tekrar canlandırılması ve devam ettirilmesi için gerekli işlemlerin ve teşviklerin biran önce yapılması inancindayı.

\section{Kaynaklar}

Aytaç, A. (2003), Hotamış Türkmen Kilimleri, Konya.

Gündoğdu, H. (2000), Kaleler ve Kuleler Kenti Ardahan, Ankara

Kırzıoğlu, F. (1953), Kars Tarihi, C. I, İstanbul.

Konukçu, E. (1999), Ardahan Tarihi, Ankara.

Önder, M. (1995), Şehirden Şehre Anadolu, Ankara.

Parlak, T. (2002), Oltu ve Köylerinde Bardı Kilimciliği, Erzurum.

Parlak, T. (2007), Çoruh Vadisinde Bitkisel Boya Potansiyeli, Ankara. 